\title{
The Propagation of Regional Shocks in Housing Markets: Evidence from Oil Price Shocks in Canada
}

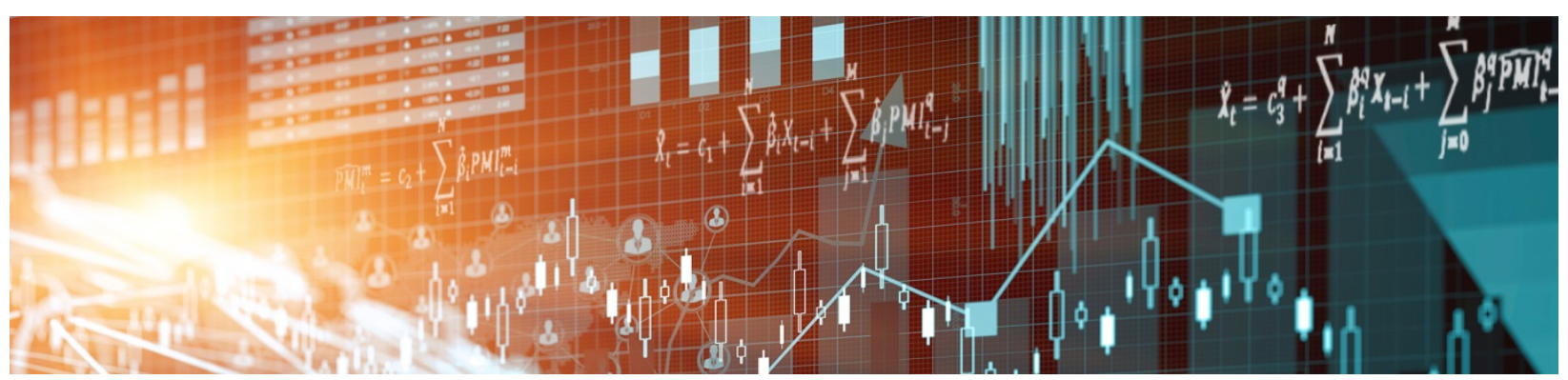

by Lutz Kilian and Xiaoqing Zhou 
Bank of Canada Staff Working Paper 2018-56

November 2018

\title{
The Propagation of Regional Shocks in Housing Markets: Evidence from Oil Price Shocks in Canada
}

\author{
by \\ Lutz Kilian ${ }^{1}$ and Xiaoqing Zhou ${ }^{2}$ \\ 1University of Michigan and CEPR \\ Ikilian@umich.edu \\ 2Financial Stability Department \\ Bank of Canada \\ Ottawa, Ontario, Canada K1A OG9 \\ xzhou@bankofcanada.ca
}




\section{Acknowledgements}

The views in this paper are solely the responsibility of the authors and should not be interpreted as reflecting the views of the Bank of Canada. We thank Duncan Whyte for excellent research assistance, and Jason Allen, Matias Cattaneo, Sonia Gilbukh, Matthew Kahn, Matthias Kehrig, Brian Peterson, Josef Schroth, Martin Stürmer, and Yasuo Terajima for helpful discussions. 


\begin{abstract}
Shocks to the demand for housing that originate in one region may seem important only for that regional housing market. We provide evidence that such shocks can also affect housing markets in other regions. Our analysis focuses on the response of Canadian housing markets to oil price shocks. Oil price shocks constitute an important source of exogenous regional variation in income in Canada because oil production is highly geographically concentrated. We document that, at the national level, real oil price shocks account for $11 \%$ of the variability in real house price growth over time. At the regional level, we find that unexpected increases in the real price of oil raise housing demand and real house prices not only in oil-producing regions, but also in other regions. We develop a theoretical model of the propagation of real oil price shocks across regions that helps understand this finding. The model differentiates between oil-producing and non-oil-producing regions and incorporates multiple sectors, trade between provinces, government redistribution, and consumer spending on fuel. We empirically confirm the model prediction that oil price shocks are propagated to housing markets in non-oilproducing regions by the government redistribution of oil revenue and by increased interprovincial trade.
\end{abstract}

Bank topics: Housing; Labour markets; Regional economic developments; Econometric and Statistical methods; International topics

JEL codes: F43, Q33, Q43, R12, R31

\title{
Résumé
}

On pourrait croire que les chocs frappant la demande de logements dans une région particulière ne touchent que le marché de l'habitation local. Dans la présente étude, nous démontrons toutefois que les conséquences de ces chocs peuvent aussi s'étendre à d'autres régions. Notre analyse porte sur la réaction des marchés canadiens du logement aux chocs des prix du pétrole. Comme la production de pétrole est très concentrée sur le plan géographique, ces chocs sont une cause exogène importante de la variation du revenu entre les régions au Canada. Nous remarquons qu'au niveau national, les chocs des prix réels du pétrole expliquent $11 \%$ de la variabilité de la croissance des prix réels des logements au fil du temps. À l'échelle régionale, nous constatons que les hausses inattendues des prix réels du pétrole font augmenter la demande de logements et les prix réels des logements non seulement dans les régions productrices de pétrole, mais aussi dans les autres régions. Afin de mieux comprendre ces résultats, nous avons élaboré un modèle théorique de la propagation des chocs des prix réels du pétrole d'une région à l'autre. Ce modèle, qui fait la distinction entre les régions productrices et non productrices, tient compte de nombreux secteurs, des échanges commerciaux entre les provinces, de la redistribution des revenus par l'État et des dépenses de consommation en 
carburant. Les données empiriques confirment la prévision du modèle : c'est par la redistribution des revenus pétroliers et par la hausse des échanges commerciaux interprovinciaux que se propagent les chocs des prix du pétrole aux marchés du logement des régions non productrices.

Sujets : Logement; Marchés du travail; Évolution économique régionale; Méthodes économétriques et statistiques; Questions internationales

Codes JEL : F43, Q33, Q43, R12, R31 


\section{Nontechnical Summary}

The traditional view is that shocks in housing markets that originate in one region are only relevant for that region. We make the case that regional shocks can have broader impacts on housing markets in other regions, even when housing markets are geographically segmented and heterogeneous. We illustrate this point using data from Canada, where oil price shocks constitute an important source of exogenous regional variation in real income. We document that such shocks raise the demand for housing and hence real house prices, even in cities and provinces where the oil industry is small or nonexistent. This empirical result stands in contrast to the implications of standard urban models of the transmission of oil price shocks to housing markets. In the latter models, higher oil prices raise commuting costs in all cities, but only oil-rich cities experience income gains. Thus, higher oil prices raise house prices in oil-rich cities, reflecting the net income gains in these cities, but lower house prices in oil-poor regions.

We develop a theoretical model of the transmission of oil price shocks across regions that helps explain why our empirical findings differ. The model differentiates between oil-rich and oil-poor regions and incorporates multiple sectors, the cost of fuel, government redistribution of oil income, and trade across provinces reflecting supply-chain linkages and higher consumer demand from oil-rich regions. Compared with standard urban models of housing markets, this model includes two additional transmission channels. In our model, the government redistribution of oil revenue across regions, as well as higher demand for intermediate goods and consumer goods produced in the oil-poor regions, stimulates real output and employment (and thus housing demand and real house prices), even in the oil-poor regions. Under weak conditions, these effects in conjunction more than offset the higher cost of fuel in oil-poor regions, causing housing demand to expand, to varying degrees, across all regions. 
We empirically validate our model by showing that existing Canadian policies of redistributing oil income from oil-rich to oil-poor provinces have succeeded at equalizing the government spending responses to oil price shocks across Canadian provinces. We also empirically confirm the model prediction that increased demand for intermediate goods and consumer goods in the oil-rich regions stimulates real output and employment in the oil-poor regions. 


\section{Introduction}

Since the global financial crisis, there has been much interest in understanding the determinants and effects of housing booms and busts. It is well documented that housing markets in major economies exhibit substantial regional heterogeneity. ${ }^{1}$ Since housing markets tend to be geographically segmented, region-specific shocks are an important determinant of house prices and housing investment. Although the role of region-specific shocks for housing markets is widely recognized, these shocks are typically considered relevant only for the housing market where they originate (see, e.g., Head, Lloyd-Ellis and Sun 2014; Cunningham, Gerardi and Shen 2017). In this paper, we establish that shocks to one regional housing market can also affect housing markets in other regions, and we identify the channels responsible for this propagation.

Understanding the sources of fluctuations in real house prices is important for understanding the business cycle because the booms and busts in housing markets tend to be associated with the overall business cycle (e.g., Bhutta 2015; Jorda, Schularick and Taylor 2016). Since housing accounts for much of household wealth and since many households borrow against their home equity, understanding the broader impact of regional shocks on real house prices has potentially important implications for the design of monetary and macroprudential policies. In addition, house price fluctuations have also been linked to educational attainment and labor market outcomes (e.g., Mian and Sufi 2014; Charles, Hurst, and Notowidigdo 2017).

Our analysis focuses on the response of Canadian housing markets to oil price shocks. Like most advanced economies, Canada has experienced substantial regional heterogeneity in housing markets (see Allen et al. 2009). As a major net oil exporter, Canada is regularly exposed to terms-of-trade shocks as the price of oil fluctuates in global markets (see, e.g., MacDonald

\footnotetext{
${ }^{1}$ For example, in the United States, house price growth varies drastically across different geographical locations (see Del Negro and Otrok 2007; Ferreira and Gyourko 2011; Bhutta and Keys 2016). For the Euro area, both house price growth and lending conditions have diverged across countries since the late 1990s (Nocera and Roma 2017).
} 
2008). An increase in the global price of oil, for example, allows Canada to turn its oil exports into more imports, in effect raising Canadian real income and stimulating domestic spending.

As the oil sold in global markets generates more export revenue, real incomes in the Canadian oil industry increase. These income gains vary substantially by region, however, since oil production is concentrated geographically, with $95 \%$ of oil produced in only three Canadian provinces: Alberta, Saskatchewan, and Newfoundland and Labrador. Thus, oil price shocks constitute large regional income shocks in Canada. We are interested in understanding the impact of these shocks on the demand for housing and on house prices. Despite the importance of the oil sector in these provinces, oil price shocks are plausibly exogenous with respect to the Canadian economy, given Canada's relatively small share in global oil production.

The starting point of our analysis is a structural vector autoregressive (VAR) model of Canadian national house prices. We show that positive shocks to the Canadian real price of oil cause persistent increases in employment and real house prices, consistent with a shift in housing demand. Real oil price shocks at the national level account for $11 \%$ of the variability in the growth rate of real Canadian house prices, compared to $4 \%$ for employment shocks and 3\% for mortgage rate shocks.

A natural question is whether the response of real house prices to oil price shocks at the national level merely reflects higher housing demand in regions where the production of oil is concentrated ("oil-rich regions") or whether it also reflects increased housing demand in regions where oil production is unimportant or nonexistent ("oil-poor regions"). We answer this question by employing an empirical strategy in the spirit of Bartik (1991) that utilizes both time series variation in the real price of oil and regional variation in the size of the oil sector, measured by the oil sector's employment share (at the city level) and its value-added share (at the province 
level). Both city-level and province-level data show that an increase in the real price of oil raises real house prices, building permits, and housing starts in all regions, with an additional positive effect on these variables in oil-rich regions. Although real house prices in oil-rich regions tend to increase the most, we find that, even in cities and provinces where the oil industry is nonexistent, house prices increase in response to positive real oil price shocks.

This evidence raises the question of how oil price shocks are propagated from the oil-rich regions to the oil-poor regions of the country. The existing literature suggests several potential channels of propagation including supply-chain linkages, interprovincial trade resulting from higher consumer demand in oil-rich provinces, and the redistribution of government revenue across provinces in the form of transfers (known as "equalization payments" in Canada). We develop a theoretical model of the propagation of oil price shocks across regional housing markets that differentiates between oil-rich and oil-poor regions and incorporates multiple sectors, government redistribution, interprovincial trade, and consumer spending on fuel. The model allows for regional differences in the responses of the housing market to oil price shocks. Comparative static analysis highlights that supply-chain linkages alone are not enough to explain the increase in real house prices in oil-poor regions in response to oil price increases, but that a sufficient degree of government redistribution of oil income to households in the oil-poor regions is. The model also highlights the importance of the labor demand channel. Even in the absence of government redistribution, interprovincial trade may raise real output, employment, and hence real house prices in oil-poor regions if there is slack in the labor market. This effect is amplified when the government spends some of its oil tax revenue on consumer goods.

Additional regression analysis at the city and province levels provides empirical support for the channels of transmission of oil price shocks across regions highlighted in the theoretical 
model. First, government revenues in oil-rich provinces increase in response to positive oil price shocks by more than in other provinces, but government expenditures in oil-rich provinces increase by no more than in other provinces, consistent with an effective redistribution of oil income across provinces. Second, we provide evidence for slack in the labor market. Higher real oil prices cause a persistent expansion in overall employment and a decline in the unemployment rate in all regions. This effect is even more pronounced in the oil-rich regions. There is no evidence of net migration from oil-poor provinces to oil-rich provinces in response to higher real oil prices, however, consistent with the literature on regional labor demand shocks (e.g., Autor, Dorn and Hanson 2013; Dix-Carneiro and Kovak 2017). Third, we show that real GDP increases in response to higher real oil prices in all provinces, consistent with an increase in the domestic demand for goods and services. Not only do we find increases in the value added of industries that produce inputs for the oil sector (such as machinery or fabricated metals), but also increases in the value added of industries not closely tied to the oil sector through the supply chain. These industries are mostly located outside the oil-rich regions. Our evidence that these responses are regionally homogeneous implies that the economic stimulus from higher oil prices is propagated to virtually all sectors and regions of the economy.

Our analysis of Canadian housing markets contributes to the literature on the relationship between housing markets and the macro economy, as well as to a growing literature on the regional propagation of shocks. For example, Feyrer, Mansur and Sacerdote (2017) quantified the spatial effects of county-level drilling shocks associated with the U.S. fracking revolution on employment and income, and Allcott and Keniston (2018) conducted a similar analysis of the effects of oil and gas booms on a range of economic outcomes including housing rents. Our analysis is also related to Kehrig and Ziebarth (2017), who studied the effects of oil supply 
shocks on U.S. regional labor markets, including the implications for real house prices, based on regional differences in the dependence on oil as an input in production. Unlike in these earlier studies, our primary focus is on the housing market. We also employ a different empirical methodology and data set, we exploit a different source of cross-sectional variation, and we provide new theoretical insights and new evidence on how oil price shocks are transmitted across regions.

The remainder of the paper is organized as follows. In section 2, we estimate the effects of shocks to the Canadian real price of oil at the national level based on structural VAR models. Section 3 reviews the economic mechanisms that allow oil price shocks to affect Canadian housing markets in all regions. Building on this discussion, we develop, in section 4, a theoretical model of the propagation of real oil price shocks from oil-rich to oil-poor regions. The implications of this model are empirically evaluated in sections 5 and 6 . The concluding remarks are in section 7 .

\section{The Effect of Oil Price Shocks on House Prices at the National Level}

Canada is the fifth largest oil producer in the world. Most Canadian crude oil is exported, with almost all oil exports going to the United States. Crude oil produced in Canada is priced in U.S. dollars in global markets. Since Canadian housing demand is determined by real income measured in Canadian consumption units, our baseline structural VAR model of the determination of Canadian real house prices in section 2.1 expresses real oil price shocks in Canadian consumption units. The real oil income generated in the oil-rich regions of Canada also depends on the real exchange rate, however. Even if the global price of oil remained unchanged, an exogenous change in the exchange rate would shift domestic income derived from oil production and hence the demand for housing. In section 2.2, we address this concern by 
showing that exogenous real exchange rate shocks are not an important source of the variation in the Canadian real price of oil, which allows us to focus on shocks to the Canadian real price of oil in the remainder of the paper.

\subsection{The Effects of Shocks to the Canadian Price of Oil on National House Prices}

As a first step, in this section we quantify the extent to which shocks to the real price of oil affect national real house prices in Canada. The upper panel of Figure 1 shows the evolution of the Teranet Canadian house price index, deflated by the consumer price index (CPI), as reported by Statistics Canada. ${ }^{2}$ The lower panel of Figure 1 shows the Canadian real price of oil, obtained by deflating the Canadian dollar price for Western Canadian Select (WCS) crude oil by the CPI. ${ }^{3}$ We analyze the relationship between these time series based on a monthly structural VAR(6) model with intercept for $y_{t}=\left(\Delta r p o i l_{t}, \Delta e m p_{t}\right.$, infl $\left._{t}, \Delta r h p_{t}, \mathrm{i}_{t}\right)$, where $\Delta r p o i l_{t}$ denotes the percentage change in the Canadian real price of oil, $\Delta e m p_{t}$ denotes the percentage change in total employment, as reported by Statistics Canada, infl denotes the rate of consumer price inflation, $\Delta r h p_{t}$ denotes the percentage change in the real house price index, and $\mathrm{i}_{t}$ denotes the 5-year fixed mortgage rate quoted by major institutional lenders, as reported by the Canadian Mortgage and Housing Corporation. ${ }^{4}$ The raw data cover March 1999 to August 2017. All data have been seasonally adjusted. ${ }^{5}$

\footnotetext{
${ }^{2}$ The Teranet National Bank Composite 11 House Price Index is constructed by the repeat-sales method based on the rate of change in home prices in 11 Canadian metropolitan areas (Calgary, Edmonton, Halifax, Hamilton, Montreal, Ottawa, Quebec City, Toronto, Vancouver, Victoria, and Winnipeg).

${ }^{3}$ The WCS price is the price for delivery at Hardisty, Alberta, expressed in Canadian dollars, and suitably extended back to 1999, as reported by the Canadian Association of Petroleum Producers. The WCS is representative of the types of crude oil produced in Canada.

${ }^{4}$ This rate is the most common mortgage rate in Canada. Very similar results are obtained when using estimates of the corresponding average effective mortgage rate.

${ }^{5}$ The lag order choice coincides with the estimate that would be obtained based on the Akaike Information Criterion with an upper bound of 12 autoregressive lags. Since the share of mining, quarrying, and oil and gas extraction in Canadian GDP has been nearly constant at about $8.5 \%$ since 1999 , we do not model variation in this share.
} 
The VAR model is identified recursively. Given that Canada is a small open economy, we treat the percentage change in the real price of oil as predetermined with respect to the Canadian economy. ${ }^{6}$ The real house price is allowed to respond to changes in employment and in the inflation rate contemporaneously, but employment is considered too sluggish to respond contemporaneously to unexpected changes in inflation, in real house prices, and in the nominal lending rate. Likewise, we rule out feedback within the current month from real house prices to consumer price inflation. The nominal mortgage rate is ordered last, allowing for the possibility that the central bank may respond contemporaneously to house prices as well as inflation and employment, thereby affecting the mortgage rate. By construction, the responses to real oil price shocks are invariant to the ordering of the model variables below the real price of oil, and the responses to mortgage rate shocks are invariant to the ordering of the model variables above the mortgage rate. All impulse-response confidence intervals are constructed based on the conditional heteroskedasticity-robust residual block bootstrap of Brüggemann, Jentsch and Trenkler (2016). ${ }^{7}$

Figure 2 focuses on three key determinants of real house prices. An unexpected increase in the real price of oil causes a statistically significant persistent increase in real house prices. The initial drop in real house prices is consistent with inflation rising faster than nominal house prices on impact. An unexpected increase in total employment also causes a statistically significant persistent appreciation of real house prices, reflecting higher labor income and hence higher housing demand. Finally, an unexpected increase in the nominal 5-year mortgage lending

\footnotetext{
${ }^{6}$ This assumption is valid even for the much larger U.S. economy (Kilian and Vega 2011).

${ }^{7} \mathrm{We}$ do not differentiate between global oil demand and oil supply shocks. This distinction is neither necessary, as discussed in section 5.3, nor feasible in practice because it would require much larger-dimensional VAR models than can be estimated on our sample starting in March 1999. Even a two-step approach, as in Kilian (2009), that involves recovering the oil demand and oil supply shocks from an oil market VAR estimated on a larger sample, before projecting Canadian variables on current and lagged values of these shocks, would be infeasible in our case.
} 
rate causes a statistically insignificant persistent decline in real house prices with a delay of one quarter as the mortgage cost rises. ${ }^{8}$

Figure 3 examines the effects of an unexpected increase in the real price of oil on Canadian macroeconomic aggregates. The estimates provide additional insights into the transmission of an unexpected oil price increase to the housing market. National employment increases persistently, consistent with an economic expansion and rising demand for housing in response to higher real oil prices. There is only a short-lived increase in inflation. The nominal lending rate increases persistently, which could be driven by the response of monetary policy or by the higher demand for capital, as the economy expands. A variance decomposition based on the estimated VAR model shows that real oil price shocks account for about $11 \%$ of the variability in the growth rate in real house prices, which is a large share given the welldocumented difficulties of explaining time series variation in asset prices. In fact, it is distinctly larger than the contribution of employment shocks (4\%) and mortgage rate shocks $(3 \%)$.

\subsection{The Role of the Exchange Rate in Measuring Oil Price Shocks}

The role of exogenous changes in the real exchange rate may be quantified by replacing the Canadian real price of oil in the baseline recursive structural VAR(6) model of section 2.1 with the real price of oil in U.S. consumption units and adding the Canadian real exchange rate as the variable ordered last. ${ }^{9}$ This allows the real exchange rate to respond to all other shocks contemporaneously. The residual shock is treated as a measure of exogenous real exchange rate variation. As Figure 4 shows, an unexpected increase in the U.S. real price of crude oil has much the same effect on employment, real house prices, inflation, and the mortgage rate as an

\footnotetext{
${ }^{8}$ This result is consistent with evidence in Glaeser, Gottlieb and Gyourko (2010), among others, that the empirical relationship between U.S. house prices and interest rates is weak.

${ }^{9}$ The nominal exchange rate data and the U.S. CPI are from FRED. The real price of Canadian crude oil in U.S. consumption units is measured by deflating the WCS price in U.S. dollars by the U.S. CPI, allowing for differences in the characteristics of Canadian crude oil from WTI or Brent crude oil (Kilian 2016).
} 
unexpected increase in the Canadian real price of oil in Figure 3. Likewise, the share of the variability of real house prices explained by these real oil price shocks is almost the same. This is direct evidence that exogenous exchange rate fluctuations may be ignored for the purpose of our analysis and lends credence to our approach of expressing the real price of oil in Canadian consumption units in the remainder of the paper.

\section{Determinants of the Response of Housing Markets to Canadian Real Oil Price Shocks}

The evidence in section 2 suggests that oil price shocks have statistically significant effects at the national level. It is not surprising that positive oil price shocks that represent income gains in oilrich regions would raise house prices and stimulate residential investment in these regions. It is less obvious, however, to what extent these shocks are propagated to other regional housing markets. In this section, we outline the channels by which real oil price shocks would be expected to affect Canadian housing markets more broadly. We first review the channels through which real oil price shocks may affect real income and hence the demand for housing and real house prices, both in oil-rich and in oil-poor provinces. We then discuss how at the same time higher real oil prices may reduce the demand for housing and lower real house prices through other channels. These insights will be used in section 4 to build a theoretical model of the regional effects of real oil price shocks that incorporates the empirically most relevant channels and that explains why higher real oil prices on balance tend to be associated with higher real house prices.

Over our sample period, as much as $78 \%$ of the crude oil produced in Canada is exported, while the share of crude oil used by the Canadian economy is only $2 \%$ of GDP on average. We therefore focus on the effects of oil price shocks on income and spending rather than on the cost of domestic production, consistent with the conventional view of how oil price shocks affect the 
economy (Kilian 2014).

\subsection{How Higher Real Oil Prices May Cause Real House Prices to Increase}

Since Canada historically has been a net exporter of crude oil, unexpected increases in the real price of oil measured in Canadian consumption units imply that Canada as a whole receives more real income. These real income gains, however, are not evenly distributed across the country. Whereas households in oil-rich provinces such as Alberta, Saskatchewan, and, more recently, Newfoundland and Labrador experience direct real income gains from higher oil prices, households in oil-poor provinces do not. The income gains associated with real oil price increases may be propagated to households in oil-poor provinces, however, by the government redistributing income across provinces, by interprovincial trade, or by migration within Canada.

Government Redistribution. Oil production generates substantial revenues for provincial governments through (i) taxes and royalties on oil production, (ii) property taxes, (iii) lease payments, and (iv) fees for the use of public land. In Alberta, for example, oil and gas royalties alone accounted for $28 \%$ of the provincial government revenue in 2008 . Oil booms also raise income tax revenue in oil-rich regions. These funds may be transferred to the federal government and redistributed across provinces, providing an economic stimulus in oil-poor provinces that increases housing demand and raises property values. ${ }^{10}$

Trade Between Provinces. An oil-poor province may also benefit from an oil boom in oil-rich regions to the extent that higher demand for goods and services from oil-rich regions stimulates

\footnotetext{
${ }^{10}$ Canada, in particular, has used this mechanism for many years. The Canadian "equalization payments" across provinces are based on a formula that calculates the difference between the per capita revenue yield that a particular province would obtain using average tax rates and the national average per capita revenue yield at average tax rates. For example, according to the Department of Finance in Canada, in 2016-17, the provinces with the largest oil sector, Alberta, Saskatchewan, Newfoundland and Labrador, and British Columbia, collectively transferred tax revenues equivalent to $\$ 2,573$ per capita to Prince Edward Island, \$2,259 per capita to New Brunswick, \$1,822 per capita to Nova Scotia, \$1,328 per capita to Manitoba, \$1,206 per capita to Quebec, and \$166 per capita to Ontario. The transfers received by the provinces can be spent in any way the provincial government desires.
} 
aggregate real output. The strength of this effect depends on the magnitude of the consumption stimulus from higher real incomes in the oil-rich region and on the degree to which oil firms rely on inputs produced in oil-poor regions.

Migration Between Provinces. In addition, increases in the demand for labor in oil-rich provinces caused by higher oil prices may stimulate net migration toward oil-producing regions. This migration increases the demand for housing in oil-rich provinces and hence house prices. At the same time, all else equal, housing demand in other provinces declines, resulting in lower property values elsewhere in the country. This channel is not likely to be quantitatively important, given the finding in the related literature on regional labor demand shocks that regional labor mobility is low (e.g., Autor, Dorn and Hanson 2013; Dix-Carneiro and Kovak 2017). Indeed, our empirical analysis in section 6 confirms that there is no interprovincial net migration to oil-rich provinces in response to oil price shocks.

Risk Sharing. Another potential channel of transmission is risk sharing, which occurs to the extent that residents of oil-poor regions hold assets of companies in oil-rich regions and residents of oil-rich regions hold assets of companies in oil-poor regions. Higher returns in oil assets, for example, allow residents in oil-poor regions to partake in the real income gains in the oil sector. The potential importance of risk sharing has been discussed in a variety of contexts. ${ }^{11}$ There are two reasons to believe that this channel is unimportant within Canada. First, private ownership of mineral rights is the exception. For example, close to $80 \%$ of the oil and natural gas rights in the oil-producing provinces of Alberta and Saskatchewan are publicly owned and much of the

\footnotetext{
${ }^{11}$ For example, Asdrubali, Sørenson, and Yosha (1996) document significant risk sharing across state borders in the United States that allows consumers to partially smooth state-level shocks. Kilian, Rebucci and Spatafora (2009) discuss risk sharing between oil-exporting and oil-importing countries at the global level. Fitzgerald and Rucker (2016) study the evidence that royalty income generated by U.S. shale oil producers is transmitted across state borders.
} 
remainder is locally owned. ${ }^{12}$ Thus, few residents outside of the oil region generate income from these rights. Second, as of 2012, more than two-thirds of Canadian oil sands production was owned by foreigners, so the majority of oil industry profits was sent abroad rather than supplementing Canadian incomes. ${ }^{13}$

\subsection{How Higher Real Oil Prices May Cause Real House Prices to Fall}

Although there are strong reasons to expect higher real oil prices to be associated with higher real house prices, as discussed in section 3.1, there are also several countervailing forces, including increases in consumer spending on fuel, environmental externalities of the oil booms triggered by higher oil prices, a possible tightening of monetary policy in response to actual or anticipated inflationary pressures from higher oil prices, and the appreciation of the Canadian dollar in response to higher oil prices. Some of these channels can be shown to be quantitatively unimportant, while others need to be incorporated into theoretical models of the regional transmission of oil price shocks.

Consumer Spending on Fuel. One channel of transmission is changes in the cost of fuel both in oil-rich and in oil-poor regions, as higher oil prices increase the cost of fuel, reducing the household income available for other purchases (e.g., Edelstein and Kilian 2009). For example, Larson and Zhao (2017) use a model incorporating changes in commuting costs to demonstrate that real house prices fall in oil-poor cities and rise in oil-rich cities in response to higher real oil prices. Thus, it is important to incorporate changes in the cost of fuel into models of the regional

\footnotetext{
${ }^{12}$ Ownership information can be found in a range of government documents and publications by interest groups such as http://publications.gov.sk.ca/documents/310/93210-

Disposition\%20Types\%20and\%20Crown\%20Public\%20Offerings.pdf and https://www.fhoa.ca/about-freeholdmineral-rights.html.

${ }^{13}$ See, e.g., "Majority of Oil Sands Ownership and Profits Are Foreign, Says Analysis," Financial Post, May 20, 2012, https://business.financialpost.com/news/majority-of-oil-sands-ownership-and-profits-are-foreign-saysanalysis.
} 
transmission of real oil price shocks to the housing market. ${ }^{14}$

Environmental Costs. There is also evidence that the oil booms associated with higher oil prices may create negative externalities that lower property values in oil-producing regions. One reason is the environmental degradation associated with oil production. For example, the risks of water contamination or other health hazards from oil production or oil spills have been associated with lower property values, the inability to insure homes, and homeowners being denied mortgages. ${ }^{15}$ Property values are also sensitive to local disamenities such as noise, traffic congestion, nighttime lights, air pollution, or the visual blight of oil rigs, oil pipelines, and land clearing. These effects, however, tend to be too local to be relevant for the transmission of oil price shocks to housing markets at the city or province level.

Monetary Policy Reactions. Actual or anticipated inflationary pressures triggered by positive oil price shocks may prompt the Bank of Canada to raise interest rates in response to higher oil prices. To the extent that such short-term interest rate responses are passed through to the 5-year mortgage rate, they may reduce the demand for housing and real house prices. Moreover, given the evidence in Allen, Clark and Houde (2014), one might expect the mortgage rate responses to oil price shocks to differ across regions. We abstract from monetary policy reactions in the theoretical analysis in section 4 for two reasons. First, the results in section 2 show that the mortgage rate responses to oil price shocks are too weak to offset the increase in real house prices caused by higher real oil prices. Second, we find no statistically significant regional

\footnotetext{
${ }^{14}$ In related work, Sexton, Wu and Zilberman (2012) show that an unexpected increase in the real price of crude oil increases the cost of commuting to work, lowering the real value of homes away from the city center and increasing foreclosure rates, as homeowners can no longer afford their mortgage payments. Molloy and Shan (2013) elaborate on this point, stressing the implications for housing demand and new housing construction.

${ }^{15}$ Boxall, Chan and MacMillan (2005) document that property values in Alberta are negatively correlated with the number of sour gas wells and flaring oil batteries located in the vicinity of the property. Related work on the impact of the fracking boom on local housing markets in the United States includes Muehlenbachs, Spiller and Timmins (2015) and Cunningham, Gerardi and Shen (2017).
} 
heterogeneity in the response of mortgage rates to oil price shocks. ${ }^{16}$ The latter result holds both for insured mortgages - consistent with the findings in Hurst et al. (2016) for the United States and for uninsured mortgages.

Exchange Rate Effects. Finally, an exogenous shock to the real price of oil in global markets causes both the real price of oil in Canadian consumption units and the Canadian real exchange rate to appreciate, complicating the analysis because oil price shocks may affect Canadian real income and hence real house prices both directly and through their effects on the competitiveness of the tradable goods sector. The results in section 2.2, however, imply that the latter effects are too small to offset the positive effect of higher global real oil prices on Canadian employment and real house prices.

\section{A Theoretical Model of the Regional and Sectoral Effects of Real Oil Price Shocks}

This section introduces a stylized model of the regional transmission of real oil price shocks to the housing market. Our model shares with standard urban models of the transmission of oil price shocks to housing markets the insight that higher oil prices raise labor incomes in oil-rich regions and hence raise real house prices, while the higher cost of motor fuel lowers the demand for housing everywhere (e.g., Larson and Zhao 2017). Unlike these earlier studies, however, our model incorporates three additional channels of transmission, namely interprovincial supplychain links, interprovincial trade in consumer goods, and the government redistribution of oil income. We abstract from risk sharing and from the responses of migration and monetary policy to oil price shocks for the reasons discussed in section 3 . The objective of the theoretical analysis is to shed light on the conditions under which real oil price shocks are transmitted to housing markets in oil-poor regions, even in the absence of real exchange rate responses. Our model is

\footnotetext{
${ }^{16}$ The average provincial mortgage rates were constructed based on quarterly proprietary loan-level micro data available to the Bank of Canada that provides information on the rate charged for each originated mortgage.
} 
simple enough to be analytically tractable. The sign of the effect of an increase in the real price of oil on real house prices in oil-rich and oil-poor regions, respectively, may be determined using comparative statics.

\subsection{Outline of the Model}

Consider a country with an oil-producing region (region 1) and a non-oil-producing region (region 2). All firms are representative. Oil is produced in region 1 by combining labor and intermediate goods. The production of intermediate goods and consumption goods takes place in region 2 . Their production uses labor only. Within region 2, labor may be freely allocated between the production of the intermediate good and the production of the consumption good. The intermediate good is sold to the oil sector in region 1. Oil and the consumption good are traded internationally. Any shortfall of these goods is met by imports. Any excess production is exported. ${ }^{17}$ Since these goods are supplied elastically from abroad, their price is determined internationally. The price of the consumption good is normalized to 1 . The real price of oil is exogenously given and is denoted by $p$. For simplicity, the cost of shipping goods domestically or internationally is set to zero.

In each region $i \in\{1,2\}$, representative households supply labor and are compensated at the real wage rate, $w_{i}$. Labor supply is inelastic in each region and immobile across regions. ${ }^{18}$

\footnotetext{
${ }^{17}$ Since oil is primarily exported, our model implies that consumer goods are imported by the Canadian economy. This assumption is consistent with evidence that, with the exception of the aircraft industry, Canada primarily exports mineral, farm, forestry, fishing, and energy products. In contrast, the consumer goods industry, the chemical industry, the auto industry, and all other manufacturing industries are net importers, consistent with the model structure.

${ }^{18}$ An alternative would have been to model households' labor-leisure choices as endogenous under additional restrictions on the utility function. Such a model would imply a counterfactual reduction in employment in region 2 in response to higher real oil prices. The reason is that, when the government redistributes oil revenue from region 1 to region 2, the windfall income gain in region 2 causes a reduction in labor supply and, hence, in total employment, which is at odds with the data.
} 
The supply of labor in region 1 is fixed. ${ }^{19}$ In region 2, labor supply may be fixed or, alternatively, there may be slack in the labor market, which is represented as the labor supply in region 2 being an increasing function of $p$. Households purchase housing services and the consumption good. Consumption and housing services are assumed to be complements. The government redistributes wealth from the oil-rich region to the oil-poor region based on a tax on oil producers' revenue, which is in part spent on consumer goods and in part redistributed directly to households in region 2 , adding to their income. Workers commute to work in both regions. The cost of motor fuel depends linearly on $p$.

Housing services are produced from land and capital. ${ }^{20}$ As in Davis and Heathcote (2007), capital represents the value of physical structures. Land is in fixed supply. The endogenously determined real price of housing services in region $i$ is denoted by $q_{i}$. Since house prices in region $i, h p_{i}$, can be expressed as the discounted sum of all future prices of housing services, we focus on the determination of $q_{i}{ }^{21}$

\subsection{Region 1: Oil-Producing Region}

Firms: Oil-producing firms are competitive and take $p$ as given. Their technology is constant returns to scale (CRS). Oil is produced from intermediate goods, $M$, supplied by region 2 and regionally supplied labor, $N_{1}$. Let $O\left(N_{1}, M\right)$ denote the output of oil in region 1 , where $N_{1}$ is the total labor supply in region 1 . The two inputs are complements, which implies that $\partial^{2} O / \partial N_{1} \partial M>0$. The government imposes a revenue tax at rate $\tau$ on oil revenue. Oil firms

\footnotetext{
${ }^{19}$ This simplifying assumption could be relaxed without affecting the signs of the responses to real oil price shocks in region 1.

${ }^{20}$ Although labor is an important input in building homes and apartments, it is not a major input in the production of housing from existing dwellings and is not considered in most urban models (Yinger 2015).

${ }^{21}$ For example, in the standard user cost model discussed in Glaeser, Gottlieb and Gyourko (2010) the house price is proportionate to the price of housing services.
} 
choose labor $N_{1}$ and $M$ to maximize $(1-\tau) p O\left(N_{1}, M\right)-w_{1} N_{1}-p^{M} M$, where $p^{M}$ denotes the price of the intermediate good. From the first-order conditions for profit maximization,

$$
\begin{aligned}
& w_{1}=(1-\tau) p \frac{\partial O}{\partial N_{1}}\left(N_{1}, M\right) \\
& p^{M}=(1-\tau) p \frac{\partial O}{\partial M}\left(N_{1}, M\right)
\end{aligned}
$$

Housing Service Providers: Our model allows both the price and the quantity of housing services to adjust to housing demand shocks. Housing services are produced from land and capital using a CRS technology. The competitive providers of housing services in region 1 choose land, $L_{1}$, and capital, $K_{1}$, to maximize $q_{1} H_{1}\left(L_{1}, K_{1}\right)-r_{1}^{L} L_{1}-r^{K} K_{1}$, where $H_{1}$ denotes the quantity of housing services provided in region $1, r_{1}^{L}$ is the rental rate of land, and $r^{K}$ is the rental rate of capital, which is assumed to be constant and determined in international capital markets. The fixed quantity of land in region 1 is owned by the households in region 1 . Profit maximization implies that

$$
\begin{aligned}
& r_{1}^{L}=q_{1} \frac{\partial H_{1}\left(L_{1}, K_{1}\right)}{\partial L_{1}}, \\
& r^{K}=q_{1} \frac{\partial H_{1}\left(L_{1}, K_{1}\right)}{\partial K_{1}} .
\end{aligned}
$$

Since $r^{K}$ and $L_{1}$ are constant, equation (3b) implies that $\partial K_{1} / \partial q_{1}>0$. Given the solution for $K_{1}\left(q_{1}\right)$ from equation (3b), equation (3a) determines $r_{1}^{L}$ for given $q_{1}$. In addition, the production function for housing services implies that the housing supply curve is upward sloping, i.e., $\partial H_{1} / \partial q_{1}>0$. The functional form of $H_{1}\left(L_{1}, K_{1}\right)$ is general enough to accommodate differences in housing supply elasticities across regions. A smaller housing supply elasticity, all else equal, implies a larger response of real house prices to a housing demand shock. 
Households: Households in region 1 choose their consumption $\left(c_{1}\right)$ and housing services $\left(h_{1}\right)$ to maximize utility $U\left(c_{1}, h_{1}\right)$ subject to $c_{1}+q_{1} h_{1}=w_{1} n_{1}+r_{1}^{L}\left(q_{1}\right) L_{1}-k_{1} p$, where $n_{1}$ is the fixed labor supply, $k_{1}$ is a constant that reflects the inelastic demand for fuel, $k_{1} p$ is the cost of fuel, and $r_{1}^{L} L_{1}$ is the rental income from land. We assume that the utility function is concave and twice differentiable. Using equation (1) and the equilibrium condition in the labor market, the budget constraint can be expressed as

$$
c_{1}+q_{1} h_{1}=\left[(1-\tau) \frac{\partial O\left(N_{1}, M\right)}{\partial N_{1}} N_{1}-k_{1}\right] p+r_{1}^{L}\left(q_{1}\right) L_{1} \equiv I_{1}\left(p, q_{1}\right)
$$

where $I_{1}\left(p, q_{1}\right)$ denotes household income. The first-order condition for $h_{1}$ implies that

$$
-q_{1} U_{c}\left(I_{1}\left(p, q_{1}\right)-q_{1} h_{1}, h_{1}\right)+U_{h}\left(I_{1}\left(p, q_{1}\right)-q_{1} h_{1}, h_{1}\right)=0 .
$$

In equilibrium, housing demand $h_{1}$ equals housing supply $H_{1}\left(q_{1}\right)$, which allows us to derive the change in the equilibrium price of housing services in response to a change in the price of oil. By the implicit function theorem,

$$
\frac{\partial q_{1}}{\partial p}=\frac{-q_{1} U_{c c}+U_{c h}}{\left(-q_{1} U_{c c}+U_{c h}\right)\left(H_{1}+q_{1} \frac{\partial H_{1}}{\partial q_{1}}-\frac{\partial I_{1}}{\partial q_{1}}\right)+U_{c}+q_{1} U_{c h} \frac{\partial H_{1}}{\partial q_{1}}-U_{h h} \frac{\partial H_{1}}{\partial q_{1}}} \frac{\partial I_{1}\left(p, q_{1}\right)}{\partial p}
$$

where $H_{1}+q_{1} \partial H_{1} / \partial q_{1}-\partial I_{1} / \partial q_{1}=r^{K} \partial K_{1} / \partial q_{1}>0$ from the definition of $I_{1}$, the zero profit condition for housing service providers, and the assumption of CRS. Since wage income exceeds the cost of fuel in the data, $\partial I_{1}\left(p, q_{1}\right) / \partial p=\left(w_{1} n_{1}-k_{1} p\right) / p>0$ for suitably chosen parameters. It follows that $\partial q_{1} / \partial p>0$ (and hence $\partial h p_{1} / \partial p>0$ ). Equation (4) also implies that the smaller the own-price elasticity of housing supply, the greater the response of the price of housing services to the oil price. Moreover, consumption also increases in response to higher oil prices, 


$$
\frac{\partial c_{1}}{\partial p}=\frac{\partial I_{1}\left(p, q_{1}\right)}{\partial p}-\left(H_{1}+q_{1} \frac{\partial H_{1}}{\partial q_{1}}-\frac{\partial I_{1}\left(p, q_{1}\right)}{\partial q_{1}}\right) \frac{\partial q_{1}}{\partial p}>0
$$

because equation (4) implies that $\left(H_{1}+q_{1} \partial H_{1} / \partial q_{1}-\partial I_{1}\left(p, q_{1}\right) / \partial q_{1}\right) \partial q_{1} / \partial p \leq \partial I_{1}\left(p, q_{1}\right) / \partial p$.

\subsection{Region 2: Non-Oil-Producing Region}

Firms: There are two types of competitive firms in region 2. Firms that produce the intermediate good employ labor, $N_{2}^{M}$, to maximize $p^{M} M-w_{2}^{M} N_{2}^{M}$ subject to $M=a N_{2}^{M}$, where $a$ denotes labor productivity in the intermediate goods sector. Profit maximization implies $w_{2}^{M}=p^{M} a$.

Firms that produce the consumption good choose $N_{2}^{C}$ to maximize $C-w_{2}^{C} N_{2}^{C}$ subject to $C=b N_{2}^{C}$, where $b$ denotes labor productivity in the consumer goods sector. Profit maximization implies $w_{2}^{C}=b$.

Since there are no frictions, workers in region 2 are indifferent to working in either industry. Thus, the real wage must be equal. Given $w_{2}^{M}=w_{2}^{C}=w_{2}$,

$$
p^{M}=b / a
$$

Hence, oil producers in region 1 can expand their production without driving up the price of intermediate goods. The quantity of the intermediate good is determined by equations (2) and (5):

$$
b / a=(1-\tau) p \partial O / \partial M\left(N_{1}, M\right) .
$$

Since the labor supply in region 1 is fixed, equation (6) determines $M$ as a function of $p$. By the implicit function theorem, the production of intermediate goods increases with the oil price, $\partial M / \partial p>0$, and, hence, so does employment in this sector, $\partial N_{2}^{M} / \partial p>0$. In other words, our model implies that, as the oil sector in region 1 expands, so does the intermediate goods sector in 
region 2 .

Housing Service Providers: The structure of this market resembles that in region 1 with suitable changes in notation.

Households: The government redistributes a fraction $\omega$ of the oil tax revenue $\tau p O$ to households in region 2 . Households in region 2 earn wage $w_{2}=b$, receive the lump-sum transfer $\omega \tau p O$, and choose $c_{2}$ and $h_{2}$ to maximize $U\left(c_{2}, h_{2}\right)$ subject to $c_{2}+q_{2} h_{2}=$ $w_{2} n_{2}+r_{2}^{L}\left(q_{2}\right) L_{2}-k_{2} p+\omega \tau p O \equiv I_{2}\left(p, q_{2}\right)$, where $n_{2}=n_{2}^{M}+n_{2}^{C}$. After imposing the labor market equilibrium condition, the budget constraint may be expressed as $c_{2}+q_{2} h_{2}=b N_{2}(p)+r_{2}^{L}\left(q_{2}\right) L_{2}$ $+\left(\omega \tau O-k_{2}\right) p$, where $N_{2}(p)$ is the endogenous total labor supply in region 2 . Note that

$$
\frac{\partial I_{2}\left(p, q_{2}\right)}{\partial p}=b \frac{\partial N_{2}}{\partial p}+\omega \tau\left(O+p \frac{\partial O}{\partial p}\right)-k_{2}
$$

is positive as long as the additional labor income and the additional government transfer received by the household exceed the additional cost of fuel:

$$
b \frac{\partial N_{2}(p)}{p}+\omega \tau p \frac{\partial O}{\partial p}+\omega \tau O>k_{2}
$$

where $\partial N_{2}(p) / \partial p \geq 0$. In that case, housing rents, house prices, and consumption increase.

\subsection{Summary of the Model Implications}

In one version of the model, $\partial N_{2}(p) / \partial p=0$ and full employment holds; in the other version, $\partial N_{2}(p) / \partial p>0$, representing slack in the labor market. Depending on which of these assumptions holds, the model implications for region 2 differ substantially. The first version of the model treats labor supply as fixed in all regions. It implies that in the absence of government redistribution of oil revenue across regions, the effect on consumption and real house prices is 
positive in the oil-rich region, but negative in the oil-poor region. Supply-chain linkages alone are not enough to raise real house prices in the oil-poor region because the expansion of the intermediate goods sectors comes at the expense of the consumer goods sector. Since aggregate real output and employment remain unchanged, so does labor income. Net income falls as fuel costs rise. Only sufficient redistribution of oil income to the oil-poor region by the government will reverse this negative sign.

In contrast, in the second version of the model, the labor supply curve in region 2 shifts to the right as the real price of oil increases. As a result, higher demand for intermediate goods and consumer goods by the oil-rich region raises aggregate real output and employment in the oilpoor region, even in the absence of government redistribution. As long as the sum of additional oil tax transfers and additional labor income in the oil-poor region exceeds the additional cost of fuel, real output, consumption, and real house prices will increase in region 2. Unlike in the previous version of the model, employment and real output in the consumer goods sector in the oil-poor region need not contract, but may expand along with the intermediate goods sector.

The next two sections empirically evaluate these model predictions based on panel regression models estimated on quarterly city- and province-level data, respectively. Section 5 focuses on the effects of oil price shocks on the regional housing markets, while section 6 considers the implications for employment, real output, and net migration. We provide evidence that the version of the model with flexible labor supplies provides a better fit to the data.

\section{The Responses of Regional Housing Markets to Oil Price Shocks}

Regions in our empirical analysis may refer to provinces or cities. Our data set consists of 33 cities, defined as metropolitan areas having at least 100,000 residents, and 9 provinces, 
respectively. ${ }^{22}$ We focus on the provinces of Alberta, British Columbia, Newfoundland and Labrador, Nova Scotia, New Brunswick, Quebec, Ontario, Manitoba, and Saskatchewan, which account for $99.2 \%$ of the Canadian population. Our analysis is mainly conducted using city-level data at quarterly frequency. We use provincial data only when city-level data do not exist. ${ }^{23}$

\subsection{Regional Data}

Our primary interest is the response of regional real house prices to oil price shocks. Quarterly city-level house price indices are constructed based on the average growth rate of the quarterly house price index across all Forward Sortation Areas (FSA) within a city. ${ }^{24}$ The FSA-level house price indices are reported by Teranet-National Bank and are based on the repeat-sales method. Quarterly provincial data for house prices are constructed by averaging the monthly average sale price by province published by the Canadian Real Estate Association (CREA). All nominal data are deflated using the appropriate provincial CPI from Statistics Canada. We also consider a range of other quarterly and annual outcome variables ranging from housing and mortgage market indicators to employment, real activity, government revenue, and government spending that are useful in evaluating the predictions of the theoretical model. ${ }^{25}$

\subsection{Empirical Strategy}

Our panel regression analysis focuses on the period 1999Q2-2017Q2, consistent with the time

\footnotetext{
${ }^{22}$ A precise definition of Census Metropolitan Areas (CMAs) can be found in the Census Dictionary of Statistics Canada.

${ }^{23}$ For example, city-level data on real gross domestic product (GDP) are only available after 2009 and there are no sectoral real GDP data at all at the city level, so we use province-level data. Likewise, quarterly data on residential mortgage loans and personal loans by banks and annual data on government expenditures and revenues are only available at the province level.

${ }^{24}$ The only exception is four cities in New Brunswick and Saskatchewan, for which no FSA data are available. We use house price data from CREA for these cities.

${ }^{25}$ The data for city-level employment, the unemployment rate, the number of residential building permits, and the number of housing starts are all from Statistics Canada. Data on the arrear rate are obtained from the Canadian

Bankers Association. Quarterly chartered bank mortgages and personal loans by province, quarterly interprovincial migration, quarterly population by province, annual provincial government expenditures and revenues, and annual provincial real GDP and real GDP classified by the North American Industry Classification System (NAICS) are all from Statistics Canada.
} 
series analysis in section 2. In estimating the response of real house prices (and other outcome variables) to Canadian real oil price shocks, we exploit two sources of variation: the variability in the real price of oil over time and the cross-sectional variation in the importance of the oil sector for the regional economy.

We measure cross-sectional differences in the exposure of regions to oil price shocks by the region-specific employment share of the oil sector or the region-specific share of the oil sector in value added prior to the shock. By allowing the shares to vary over time rather than fixing them at their average values, we capture changes in the importance of the oil industry in each region over time. At the city level, there is no alternative to using employment shares. In practice, the employment share is defined as the most recent two-quarter moving average of the employment share for "mining, quarrying, and oil and gas extraction," which represents the finest sectoral disaggregate of the employment data available. Figure 5 shows the standardized employment share weights for Calgary in Alberta, Saskatoon in Saskatchewan, and Vancouver in British Columbia. It documents substantial variation in the importance of the oil industry across cities and over time, which helps identify the regional responses to real oil price shocks.

At the province level, we instead interact real oil price changes with the share of "mining, quarrying and oil and gas extraction" in provincial value added prior to the change in the real price of oil. The value-added share for Alberta, for example, rose from 19\% in 1999 to a peak of $33 \%$ in 2005 , before declining back to $17 \%$ by 2016 , reflecting the rise and decline of the oil sands industry. In contrast, the value-added share for Ontario remained at approximately $1 \%$ throughout the estimation period. ${ }^{26}$

\footnotetext{
${ }^{26}$ The estimates at the province level are generally robust to the choice of the share measure, when both are available. The main substantive difference is that the value added share tends to produce more statistically significant estimates for government spending and revenues, which is expected since the latter respond to oil tax revenues rather than oil sector employment.
} 
Our empirical strategy exploits the interaction of time series variation in real oil prices with cross-sectional variation in regions' exposure to the oil sector, in the spirit of Bartik (1991). Because we are making use of a comparatively clean source of exogenous variation, as discussed later, the causal effects of changes in the real price of oil can be estimated using the panel regression model,

$$
\Delta^{h} y_{i, t}=\beta_{0}^{h}+\beta_{1}^{h} \Delta^{h} p_{t}+\beta_{2}^{h} \Delta^{h} p_{t} \times \bar{s}_{i, t-h}+\beta_{3}^{h} \bar{s}_{i, t-h}+\sum_{q=1}^{3} \delta_{q}^{h} D_{q}+\gamma_{i}+\varepsilon_{i, t}^{h},
$$

where $\Delta^{h} y_{i, t}$ denotes the percent change between quarters $t-h$ and $t$ in the economic outcome of interest (say, the real house price) in region $i ; \Delta^{h} p_{t}$ denotes the percent change in the real price of oil over the same period; $\bar{s}_{i, t-h}$ denotes the standardized employment share (or value added share) prior to the change in the price of oil; $D_{q}, q=1,2,3$, denotes a quarterly seasonal dummy variable; and $\gamma_{i}$ denotes a set of regional fixed effects that absorb any time-invariant heterogeneity. The error term $\varepsilon_{i, t}^{h}$ denotes idiosyncratic shocks specific to region $i$.

Given that $\bar{S}_{i, t-h}$ is predetermined, the total causal impact of an increase in the real price of oil on real house prices in region $i$ over horizon $h$ is captured by

$$
\beta_{1}^{h}+\beta_{2}^{h} \bar{s}_{i, t-h}
$$

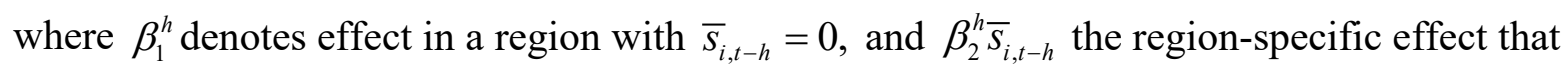
depends on the importance of the oil sector for the regional economy, as measured by departures of the share from zero. ${ }^{27}$

\footnotetext{
${ }^{27}$ As an additional robustness check, we replaced $\Delta^{h} p_{t}$ in equation (7) by quarterly fixed effects that absorb all common shocks at the aggregate level. The resulting time fixed-effects model, $\Delta^{h} y_{i, t}=\beta_{0}^{h}+\beta_{2}^{h} \Delta^{h} p_{t} \times \bar{s}_{i, t-h}+$ $\beta_{3}^{h} \bar{s}_{i, t-h}+\gamma_{i}+\delta_{t}+\varepsilon_{i, t}^{h}$, produced very similar estimates of $\beta_{2}^{h}$. We therefore report only the estimates of model (7).
} 
The standard errors are clustered at the regional (city or province) level. Because the number of clusters is small in our analysis, conventional cluster-robust asymptotic standard errors are not valid. Throughout the paper, we therefore report fixed-design wild bootstrap $p$-values for $\hat{\beta}_{1}^{h}$ and $\hat{\beta}_{2}^{h}$ clustered at the regional level, as discussed in Cameron, Gelbach and Miller (2008). ${ }^{28}$

\subsection{Identification of Causal Effects}

The causal interpretation of $\beta_{1}^{h}$ and $\beta_{2}^{h}$ rests on the assumption that changes in the real price of oil are exogenous with respect to the Canadian economy, that they are unpredictable, and that they are not correlated with exogenous changes in other variables that affect the Canadian economy. These assumptions make sense for the following reasons.

As to the first condition, Canada is a small open economy, so Canadian demand for oil does not affect the global price of oil. Moreover, since Canadian oil producers account for only $4 \%$ of world oil production, they are too small to influence the global price of oil and take the price of oil as exogenously given.

As to the second condition, recent research shows that consumers treat the current real price of oil as the best predictor of the future real price of oil (see, e.g., Anderson et al. 2011; Anderson, Kellogg and Sallee 2013; Alquist, Kilian and Vigfusson 2013). Since there is no evidence that firms are better at predicting the price of oil than households, we postulate that firms and consumers alike perceive all changes in the real price of oil as permanent shocks.

As to the third condition, one concern is that some exogenous shock may shift both the

\footnotetext{
The advantage of model (7) compared with the time fixed-effect panel model is that it allows us to assess the total effect of changes in the real price of oil on each region.

${ }^{28}$ Because the number of clusters is small, the fixed effect cannot be estimated consistently, invalidating conventional bootstrap confidence intervals and standard errors. Asymptotically valid $p$-values may be constructed by bootstrapping the model under the null hypothesis of zero coefficients (Canay, Santos and Shaikh 2018).
} 
real price of oil and other variables affecting the Canadian economy, violating the all-else-equal premise of causal inference. For example, increases in the real price of oil associated with an exogenous boom in the global economy emanating from emerging Asia may be correlated with increases in the real price of other Canadian export commodities. Our analysis of the Canadian merchandise trade balance, however, shows not only that oil accounts for the bulk of Canadian net export earnings, but that there is little comovement between the price of oil and the prices of other important export commodities (such as lumber) during our estimation period, allowing us to abstract from this concern. Likewise, Canadian manufactured exports do not appear to increase systematically during the global economic boom of the 2000s, suggesting that demanddriven real oil price increases are not associated with a direct stimulus for the Canadian economy.

A related concern is that the Chinese economic boom of the 2000s may have been associated both with an increase in the real price of oil and with increasing purchases by Chinese real estate investors in Canada. Housing market data, however, show that foreign home owners account for less than 1\% of home ownership in most Canadian cities. Only in Vancouver and Toronto is this share higher with $2.6 \% .{ }^{29}$ Our results are robust to excluding Vancouver and Toronto from the panel regressions, indicating that this additional link, if it exists, is not quantitatively important.

Yet another concern is that the increased global demand for crude oil and other industrial commodities in the 2000 s coincided with the increased availability of inexpensive consumer goods imports from emerging Asia, representing a favorable terms-of-trade shock, as Canadian import prices dropped. Our VAR analysis, however, suggests that this effect must be small,

\footnotetext{
${ }^{29}$ Source: Canada Mortgage and Housing Corporation: https://www.newswire.ca/news-releases/non-residentownership-of-condo-apartments-remains-low-and-stable-cmhc-665176373.html.
} 
because a positive real oil price shock permanently raises the level of Canadian consumer prices (see Figure 3).

A final concern is that exogenous oil supply disruptions caused by wildfires, power outages, or unexpected oil pipeline shutdowns in Canada may simultaneously affect the real price of Canadian crude oil and real house prices in Canada. There are three such events in particular: The wildfire near Fort McMurray in Alberta in May 2016, the power outage in the same area in mid-2018, and a shutdown of the Keystone pipeline from Canada to the United States following a pipeline rupture in South Dakota in November 2017. The pipeline shutdown and power outage occurred after the end of our sample. Events such as these do not undermine our identification. First, none of these events occurred close to a city. Notably, Fort McMurray is not included in our sample of Canadian cities because its population is too small. Second, even a shutdown of $10 \%$ of Canadian oil production for two months has a negligible effect on annual real value added in Canada and in Alberta, given the comparatively low share of the oil sector in GDP. This fact limits the effects of such events on labor income and housing demand outside of Fort McMurray. Third, our panel regression results are robust to terminating the sample after 2016Q1 (before the wildfire) and to including 2016Q2 dummies for all cities in Alberta.

\subsection{Responses of Regional House Prices to Oil Price Shocks}

Figure 6 shows the values of $\hat{\beta}_{1}^{h}$ and $\hat{\beta}_{2}^{h}$ obtained from quarterly city-level data by estimating equation (7) separately for each $h$ and each dependent variable. Estimates that are statistically significant at the 5\% level are marked as filled circles and estimates that are significant at the $10 \%$ are marked as empty circles. For a city with a zero standardized employment share, the estimate of $\beta_{1}^{h}$ for real house prices is slightly negative at quarterly frequency, because nominal house prices are sticky and inflation rises in the short run. At lower frequency, real house prices 
increase steadily in response to an increase in the real price of oil, and the response becomes statistically significant. The cumulative effect approaches 0.03 percentage points for annual growth rates and 0.06 percentage points for biennial growth rates. The corresponding estimates of $\beta_{2}^{h}$ show that oil-rich cities experience an additional increase in real house prices in response to higher real oil prices (and oil-poor cities a correspondingly smaller increase), but this incremental response is more gradual, reaching 0.03 percentage points when using biennial growth rates. The estimates of $\beta_{2}^{h}$ are statistically significant at the $10 \%$ level at lower frequency. ${ }^{30}$

Our estimates allow us to assess the total impact of real oil price shocks on each regional housing market based on equation (8), controlling for the importance of the oil sector at each point in time. To illustrate the regional heterogeneity in the propagation of oil price shocks, consider the example of two cities: Vancouver with a standardized employment share near -0.6 in 2008Q2 and Calgary with a standardized employment share in excess of 3. From equation (8), the resulting total effect of a positive $1 \%$ real oil price shock on real house prices in Calgary is a $0.03 \%$ increase based on annual growth rates and a $0.16 \%$ increase based on biennial growth rates, whereas the total effect on real house prices in Vancouver is a $0.03 \%$ increase and a $0.04 \%$ increase, respectively. Despite this heterogeneity, we find that, even for the lowest standardized employment share, the effect of real oil price shocks on real house prices remains positive. ${ }^{31}$

\footnotetext{
${ }^{30} \mathrm{We}$ also experimented with an alternative model specification that allows for asymmetric responses to changes in the real price of oil. We examined the alternative hypothesis that a decline in the real price of oil lowers house prices beyond the effect associated with any percent change in the real price of oil. To minimize the risk of data mining across horizons we focused on the two-year horizon. There was no statistically significant asymmetry in the response of real house prices for either $\beta_{1}^{h}$ or $\beta_{2}^{h}$.

${ }^{31}$ An additional, empirically testable implication of the theoretical model in section 4 is that, if there are multiple cities within a region, all else equal, the cities with a less elastic housing supply should experience higher house price growth in response to a positive oil price shock. Since we are not aware of a well-established measure for the Canadian housing supply elasticity at the city level, comparable to the estimates for U.S. metropolitan housing markets in Saiz (2010), we leave this question for future research.
} 
We conclude that real house prices respond to oil price shocks in all regions, but more so in oil-rich regions. One potential explanation of this result is that oil price shocks only have region-specific effects and that the differences in house price responses simply reflect the greater exposure to oil price changes in oil-rich regions. This interpretation, however, is inconsistent with the fact that we find responses in real house prices even in cities such as Quebec City or Winnipeg, where oil production is virtually nonexistent. The other explanation is that these shocks are propagated from the oil-rich regions of Canada to oil-poor regions. Before returning to this point and providing more direct evidence in support of spillovers from oil-rich regions to housing markets elsewhere in Canada, it is useful to examine the responses of other housing market indicators.

\subsection{Responses of Other Housing Market Variables to Oil Price Shocks}

The regional effects of changes in the real price of oil on real house prices do not take place in isolation. Such shocks also affect residential investment. The upper panel of Figure 6 shows that, in a city with the average employment share, the increase in the real house price caused by an increase in the real price of oil coincides with a temporary, highly statistically significant increase in the number of building permits and housing starts for single-family homes. The lower panel of Figure 6 shows an additional statistically significant increase in these variables in oilrich cities. This evidence confirms the interpretation of real oil price shocks as housing demand shocks.

\subsection{Implications for Mortgage Markets}

One of the reasons policymakers are interested in quantifying the relationship between oil prices and house prices is the perception that higher oil prices in the 2000s stimulated household borrowing by raising the value of homes. Figure 7 focuses on the implications of real oil price 
shocks for mortgage markets. Based on data at the province level, higher real oil prices cause a declining percentage of mortgages in arrears, as well as increased consumer borrowing and rising mortgage values. The pattern of these responses mirrors that of the responses of real house prices. This fact suggests that Canadian households borrow against their home equity and accumulate debt in response to higher oil prices. There is no statistically significant regional heterogeneity in the responses of these financial variables. ${ }^{32}$

\section{How Do Oil Price Shocks Propagate Across Regions?}

In this section, we provide direct evidence that oil price shocks that generate direct income gains in oil-producing regions are propagated to non-oil-producing regions, causing real house prices to increase in all regions. We study the responses of a range of additional outcome variables based on the panel regression model (7). The choice of these variables is guided by the theoretical model in section 4. In section 6.1, we show that overall employment increases in response to higher real oil prices in all regions, even in regions where oil production is virtually nonexistent. This result supports the version of the theoretical model that allows for shifts in the labor supply in response to higher oil prices. In section 6.2, we show that the real output of industries that support the oil sector expands as the real price of oil price increases, consistent with the model implication that supply-chain linkages are one of the propagation channels. In addition, the real output of many industries that are not directly related to oil production also increases, reflecting higher consumer demand and higher government purchases financed by oil tax revenues. The latter channel is explored in more detail in section 6.3. Although our regression framework does not allow us to quantify the contribution of these channels separately,

\footnotetext{
${ }^{32}$ The mortgage value responses are based on a shorter sample ending in 2011Q2, given a major change in the definition of mortgage values, as reported by banks, which results in a discontinuous jump in mortgage values in 2011Q3.
} 
it provides direct empirical support for the importance of each of these channels in propagating regional shocks.

\subsection{Regional Labor Market Responses}

As the demand for goods produced in region 2 increases, the unemployed in that region are more likely to find gainful employment, while individuals who had left the labor force at an earlier stage may choose to return to the labor market in their region. As employment and labor income rise, so does the demand for housing. Figure 8 examines the labor market responses to positive real oil price shocks based on quarterly city-level data. The upper panel confirms that cities with an average oil employment share experience an increase in real house prices, a persistent decline in the unemployment rate, and an increase in employment. There is also a small but statistically significant increase in oil employment in response to higher real oil prices. ${ }^{33}$ Based on equation (8), even for the city with the lowest standardized employment share, the effect of a positive oil price shock on total employment is positive. For oil-rich provinces, there is an additional decline in the unemployment rate and an additional increase in total employment and in oil employment, as shown in the lower panel of Figure $8 .{ }^{34}$

\subsection{Regional Migration Responses}

Another possibility not considered in the theoretical analysis is that the labor supply in region 1 may increase as a result of net migration from oil-poor provinces. Additional regression analysis in the appendix, however, shows that increases in the real price of oil do not cause net migration

\footnotetext{
${ }^{33}$ This increase is expressed as a share of total employment prior to the real oil price increase, since oil employment is small.

${ }^{34}$ Further regression results (not shown to conserve space) show that the responses of the labor force are similar to those for employment, suggesting that workers who previously left the labor force choose to return in response to better employment opportunities. Average hours worked increase in oil-rich provinces, but not elsewhere. The nominal wage increases everywhere, but more so in oil-rich provinces. The real wage, however, increases in oil-rich provinces only. These results are consistent with increases in employment being made possible by a combination of reductions in unemployment and increases in the labor force, which helps alleviate the upward pressure on the real wage.
} 
into oil-rich provinces, which motivates the exclusion of the migration channel from the model in section 4 (see Figure A1). ${ }^{35}$ Our point is not that there has not been substantial interprovincial net migration into the Canadian oil provinces since 1999, but that the evolution of this net migration over time is not explained by changes in the real price of oil. As the appendix shows, the latter result is not surprising, given that net interprovincial migration to Alberta dropped sharply in 2007-08, amidst severe labor shortages, while the real price of oil rose dramatically. At the same time, net migration to Sasketchawan increased dramatically well before the 2007/08 surge in the real price of oil, but dropped sharply, when the oil price surged (see Figure A2). ${ }^{36}$

It should be noted that the migration data underlying our analysis reflect the change in the tax residency of individuals. They do not include oil-sector workers who spend only part of the year working in oil-rich regions. Such temporary migrant workers have to declare their employment in the oil sector in the oil-poor region where they officially reside. The right panel of Figure 8, however, implies that oil employment in oil-poor regions does not increase in response to higher oil prices, suggesting that temporary migration is not important. This conclusion is also consistent with data on aircraft movements in and out of major Canadian metropolitan area airports from Nav Canada, the company operating the Canadian civil air navigation system. ${ }^{37} \mathrm{We}$ find no evidence that the number of aircraft going into oil-rich cities increases at a faster rate in response to higher real oil prices than the number of aircraft going into other cities (see Figure A3).

\footnotetext{
${ }^{35}$ In related work, Kehrig and Ziebarth (2017) provided evidence in a different context that regional migration in the United States increases in response to oil supply shocks. Their study, however, focused on in-migration rather than net migration. We also find evidence of statistically significant positive coefficients for in-migration, but these effects are offset by the positive coefficients for out-migration, resulting in statistically insignificant coefficients for net migration that are close to zero.

36 "Recent Migration Trends in Census Divisions: Fort McMurray, Calgrary and Edmonton," Government of Alberta, Demographic Spotlight, March 2011, https://open.alberta.ca/dataset/6a962a43-f03d-4028-bc8813391a8c71d4/resource/55750587-fd42-4823-8a69-354758ba67eb/download/2011-0311-migration-trends-fortmcmurray-calgary-edmonton.pdf.

${ }^{37}$ The flight data were obtained from Statistics Canada.
} 
Finally, our response estimates are consistent with census data on regional migration patterns that show that the majority of migrants living in Edmonton and Calgary arrived from within the same province, from other oil provinces, or from abroad (e.g., Amirault, de Munnik and Miller 2013). Data for the oil town Fort McMurray, for example, suggest that about half of the migrants to Fort McMurray are from within Alberta, 17\% are from the oil province Newfoundland and Labrador, and about $10 \%$ are foreigners, leaving at most one in five migrants from any of the oil-poor provinces.

\subsection{Responses of Regional Real Output}

The version of the model in section 4 with flexible labor supplies predicts an increase in real output in both regions in response to an increase in the real price of oil. The first row of Table 1 shows estimates of $\beta_{1}^{h}$ and $\beta_{2}^{h}$ for annual and biennial real GDP growth at the province level. ${ }^{38}$ Like the employment responses in section 6.1, the responses of aggregate real GDP are statistically significant and positive for all provinces, even those with the lowest exposure to the oil industry. This evidence corroborates the conclusions based on the labor market data and strengthens the empirical support for the assumption of flexible labor supplies. The economic expansion caused by positive real oil price shocks strengthens at longer horizons for oil-rich provinces, but weakens for oil-poor provinces, suggesting that the economic expansion in oilpoor provinces is comparatively short-lived. Next, we examine in more detail the empirical support for the interprovincial trade channels of the transmission of oil price shocks to oil-poor regions highlighted in the theoretical analysis. We start with the role of supply-chain linkages and then examine the role of higher consumer demand.

\footnotetext{
${ }^{38}$ The raw data are annual. All sectoral responses have been expressed as a share of real GDP prior to the real oil price increase, since in many provinces the value added of one type or another is so small that percentage changes in sectoral value added paint a misleading picture when comparing across provinces.
} 


\subsubsection{The Role of Supply-Chain Linkages}

The flexible labor-supply version of the model in section 4 implies that the intermediate goods sector should expand, but that the consumer goods sector may expand or fall, depending on the strength of the regional transmission mechanism. Verifying the model prediction about increased growth in the intermediate goods sector in response to higher oil prices is difficult because we do not know the extent to which a given sector provides intermediate goods for oil-rich regions. In Table 1 we present results for the mining sector and for the manufacturing sector, which, according to the analysis in Allcott and Keniston (2018), account for most of the inputs supplied to the oil sector.

As expected, Table 1 shows a tightly estimated positive response of mining, quarrying, and oil and gas extraction, along with activities that directly support these industries. We also find highly statistically significant increases in the annual growth rates of a broad range of manufacturing activities that are related to oil production, with little or no evidence of regional heterogeneity in this response, as measured by the absence of statistically significant $\hat{\beta}_{2}^{h}$ values. This pattern is inconsistent with the hypothesis that the economic stimulus should be stronger in oil-rich regions in the absence of regional spillovers, providing direct support for the existence of spillovers from oil-rich to oil-poor regions. In fact, Table 1 shows that manufacturing responds more strongly in oil-poor regions than in oil-rich regions, given that $\hat{\beta}_{2}^{1 y r}<0$. Thus, there is strong evidence in support of the supply-chain links highlighted in the theoretical analysis. In the biennial data, the responses of several of the components of manufacturing value added remain statistically significant, but not the overall response.

\subsubsection{The Role of Higher Consumer Demand}

Table 2 shows the annual value added in the remaining sectors of the economy exhibits a 
statistically significant positive response to higher oil prices. The first three rows focus on wholesale trade, retail trade, and transportation and warehousing. The highly statistically significant responses in wholesale and retail trade, in particular, across all provinces are consistent with an increase in consumer demand, as predicted by the theoretical model. The next seven rows focus on the service sector. Again, there is a pattern of positive and statistically significant responses across the board and little or no evidence of regional heterogeneity, providing evidence of spillovers across regions. The particularly strong response of professional, scientific, and technical services suggests that this sector provides additional support services for the oil industry in response to higher oil prices.

The positive response of construction may reflect the increase in residential housing demand, but could also be indicative of increased demand for roads and industrial infrastructure, while the positive response of utilities suggests increased demand for water and power. Finally, the positive response of public administration services in all provinces is suggestive of increases in government spending driven by the redistribution of oil tax revenue, as discussed in section 6.4 .

\subsection{The Role of Government Redistribution of Oil Tax Revenue}

Canada pursues an active policy of redistributing government revenue from rich provinces to poor provinces. These transfers are known as "equalization” payments. A province is considered rich, if its per capita government revenue exceeds the national average. Provinces with lower than average per capita tax revenue receive transfer payments from the federal government. Receiving provinces may spend these transfers as they see fit. Over our sample period, the rich provinces have coincided with the most oil-rich provinces in Canada, allowing us to interpret this 
equalization program as a mechanism for redistributing oil tax revenue from oil-rich to oil-poor provinces.

The theoretical model in section 4 predicts that $\partial q_{2} / \partial p>0$ if

$$
\underbrace{p b \frac{\partial N_{2}(p)}{\partial p}}_{+}+\underbrace{\omega \tau p^{2} \frac{\partial O}{\partial p}}_{+}+\omega \tau p O>k_{2} p .
$$

Since the first term is weakly positive by assumption and the second term is strictly positive for $0<\omega \tau<1$, a sufficient condition for $\partial q_{2} / \partial p>0$ is $\omega \tau p O>k_{2} p$, i.e., the magnitude of the direct fiscal transfer to households in region 2 must exceed the fuel cost in region 2 .

One way of gauging the quantitative importance of the equalization transfers is a thought experiment in which the entire oil tax revenue is redistributed to households $(\omega=1)$. We would expect an income stimulus in oil-poor provinces whenever the equalization payments per capita received by an oil-poor province exceeds per capita spending on motor fuel. Table 3 shows that, on average, the equalization payments are almost twice as large as the spending on motor fuel, suggesting that the degree of government redistribution is large enough to matter and that the equalization of government spending across provinces is likely to play a central role in the transmission of oil price shocks in Canada.

This conclusion is corroborated by more direct evidence on the responses of government revenue and government spending by province. Table 4 presents results of a formal test of the hypothesis of regional homogeneity in government revenues and in government expenditures by province. Regional homogeneity implies that $\beta_{2}^{h}$ is zero in equation (7). Using annual data, the $t$-test of $H_{0}: \beta_{2}^{h}=0$ rejects the null of regional homogeneity at the $5 \%$ level for government revenue and at the $10 \%$ level for government expenditures, as shown in the upper panel of Table 4. This finding is not surprising because equalization payments will only be made with a delay of 
up to one year. The lower panel of Table 4 is based on the biennial data. It shows that, in the average province, an increase in the real price of oil causes a statistically significant increase in government revenue as well as in government expenditures, consistent with a general economic expansion. Whereas a $t$-test of $H_{0}: \beta_{2}^{h}=0$ rejects the null of regional homogeneity in government revenue at the $5 \%$ level, it does not reject this null for government expenditures. In other words, although government revenues in oil-rich provinces increase by more than in the average province in response to positive real oil price shocks, government expenditures in oilrich provinces do not increase by more than in the average province. This pattern is consistent with the interpretation that the redistribution of income across provinces through interprovincial transfers is effective.

\subsection{Summary of the Model Evaluation}

Our analysis shows that there is empirical evidence for all three channels of propagation highlighted in the theoretical analysis. The alternative view that regional variation in the real income gains associated with oil price increases alone can explain the responses of regional and national house prices implies that regions in which the oil sector is large should experience a larger boom in government spending, manufacturing, and consumer spending than oil-poor regions. This prediction is at odds with the regional homogeneity in the responses of government spending, consumer spending, and manufacturing to oil price shocks documented in Tables 1, 2, and 4 . The regional homogeneity in these responses can only be explained by the regional propagation of oil price shocks, as predicted by our theoretical analysis. The resulting stimulus for the economy in the oil-poor regions also helps explain why net migration from oil-poor to oil-rich provinces in response to higher oil prices is not important in the data. 


\section{Conclusion}

The traditional view is that shocks in housing markets that originate in one region are only relevant for that region. We made the case that regional shocks can have broader impacts on housing markets in other regions, even when housing markets are geographically segmented and heterogeneous. We illustrated this point using data from Canada, where oil price shocks constitute an important source of exogenous regional variation in real income. We documented that such shocks raise the demand for housing and hence real house prices, even in cities and provinces where the oil industry is small or nonexistent. This empirical result stands in contrast to the implications of standard urban models of the transmission of oil price shocks to housing markets. In the latter models, higher oil prices raise the cost of commuting in all cities, but only oil-rich cities experience income gains. Thus, higher oil prices raise house prices in oil-rich cities, reflecting the net income gains in these cities, but lower house prices in oil-poor cities (e.g., Yinger 2015; Larson and Zhao 2017).

We developed a theoretical model of the transmission of oil price shocks across regions that helps explain why our empirical findings differ. The model differentiates between oil-rich and oil-poor regions and incorporates multiple sectors, fuel costs, government redistribution of oil income, and trade across provinces reflecting supply-chain linkages and higher consumer demand from oil-rich regions. Compared with standard urban models of housing markets, this model includes two additional transmission channels. In our model, the government redistribution of oil revenue across regions, as well as higher demand for intermediate goods and consumer goods produced in the oil-poor regions, stimulates real output and employment (and thus housing demand and real house prices) even in the oil-poor regions. Under weak conditions, these effects in conjunction more than offset higher fuel costs in oil-poor regions, causing 
housing demand to expand, to varying degrees, across all regions.

We empirically validated our model by showing that existing Canadian policies of redistributing oil income from oil-rich to oil-poor provinces have succeeded at equalizing the government spending responses to oil price shocks across Canadian provinces. We also empirically confirmed the model prediction that increased demand for intermediate goods and consumer goods in the oil-rich region will stimulate real output and employment in the oil-poor region.

The fact that oil price shocks not only affect housing demand in oil-rich regions, but also affect housing demand in oil-poor regions has important implications for economic policy. For example, it eases concerns that a common interest rate policy may not be equally appropriate for oil-rich and oil-poor regions. Moreover, it suggests that regulators of mortgage markets in oilpoor regions must take account of the propagation of oil price shocks to their region. We also established a direct link from oil price shocks to household debt and bank lending, which matters for monitoring and predicting risks in credit markets. Finally, our evidence of a systematically positive response to higher oil prices of the value added in the Canadian manufacturing sector casts doubt on the view that Canada is suffering from the Dutch Disease.

\section{References}

Allcott, H., and D. Keniston (2018), "Dutch Disease of Agglomeration? The Local Economic Effects of Natural Resource Booms in Modern America," Review of Economic Studies, $85,695-731$.

Allen, J., Amano, R., Pyrne, D.P, and A.W. Gregory (2009), “Canadian City Housing Prices and Urban Market Segmentation," Canadian Journal of Economics, 42, 1132-1149. 
Allen, J., Clark, R., and J.-F. Houde (2014), “Price Dispersion in Mortgage Markets," Journal of Industrial Economics, 62, 377-416.

Alquist, R., Kilian, L., and R.J. Vigfusson (2013), "Forecasting the Price of Oil,” in: G. Elliott and A. Timmermann (eds.), Handbook of Economic Forecasting, 2, Amsterdam: NorthHolland, 427-507.

Amirault, D., de Munnik, D., and S. Miller (2013), “Explaining Canada’s Regional Migration Patterns," Bank of Canada Review, Spring, 16-28.

Anderson, S.T., Kellogg, R. and J.M. Sallee (2013), "What Do Consumers Believe about Future Gasoline Prices," Journal of Environmental Economics and Management, 66, 383-403.

Anderson, S.T., Kellogg, R., Sallee, J.M., and R.T. Curtin (2011), "Forecasting Gasoline Prices Using Consumer Surveys," American Economic Review Papers \& Proceedings, 101, $110-114$

Asdrubali, P., Sørensen, B.E., and O. Yosha (1996), “Channels of Interstate Risk Sharing: United States 1963-1990," Quarterly Journal of Economics, 111, 1081-1110.

Autor, D., Dorn, D., and G. Hanson (2013), “The China Syndrome: Local Labor Market Effects of Import Competition in the United States," American Economic Review, 103, 21212168.

Bartik, T. (1991), Who Benefits from State and Local Economic Development Policies? W.E. Upjohn Institute for Employment Research: Kalamazoo, MI.

Bhutta, N. (2015), “The Ins and Outs of Mortgage Debt during the Housing Boom and Bust," Journal of Monetary Economics, 76, 284-298.

Bhutta, N., and B.J. Keys (2016), "Interest Rates and Equity Extraction during the Housing Boom," American Economic Review, 106, 1742-1774. 
Boxall, P.C., Chan, W.H., and M.L. MacMillan (2005), “The Impact of Oil and Natural Gas Facilities on Rural Residential Property Values: A Spatial Hedonic Analysis," Resource and Energy Economics, 27, 248-269.

Brüggemann, R., Jentsch, C., and C. Trenkler (2016), "Inference in VARs with Conditional Heteroskedasticity of Unknown Form," Journal of Econometrics, 191, 69-85.

Cameron, A.C., Gelbach, J. B., and D.L. Miller (2008), "Bootstrap-Based Improvements for Inference with Clustered Errors," Review of Economics and Statistics, 90, 414-427.

Canay, I.A., Santos, A., and A.M. Shaikh (2018), “The Wild Bootstrap with a 'Small' Number of 'Large' Clusters," manuscript, Northwestern University.

Charles, K.K., Hurst, E., and M.J. Notowidigdo (2017), “Housing Booms and Busts, Labor Market Outcomes and College Attendance," forthcoming: American Economic Review.

Cunningham, C., Gerardi, K., and Y. Shen (2017), "Fracking and Mortgage Default,” Working Paper 2017-4, Federal Reserve Bank of Atlanta.

Davis, M.A., and J. Heathcote (2007), "The Price and Quantity of Residential Land in the United States," Journal of Monetary Economics, 54, 2595-2620.

Del Negro, M., and C. Otrok (2007), "99 Luftballons: Monetary Policy and the House Price Boom across U.S. States," Journal of Monetary Economics, 54, 1962-1985.

Dix-Carneiro, R., and B.K. Kovak (2017), “Trade Liberalization and Regional Dynamics,” American Economic Review, 107, 2908-2946.

Edelstein, P., and L. Kilian (2009), "How Sensitive Are Consumer Expenditures to Retail Energy Prices?" Journal of Monetary Economics, 56, 766-779.

Ferreira, F., and J. Gyourko (2011), “Anatomy of the Beginning of the Housing Boom: U.S. Neighborhoods and Metropolitan Areas, 1993-2009," NBER Working Paper No. 17374. 
Feyrer, J., Mansur, E.T., and B. Sacerdote (2017), “Geographic Dispersion of Economic Shocks: Evidence from the Fracking Revolution," American Economic Review, 107, 1313-1334.

Fitzgerald, T., and R.R. Rucker (2016), “U.S. Private Oil and Natural Gas Royalties: Estimates and Policy Relevance," OPEC Energy Review, 40, 3-25.

Glaeser, E.L., Gottlieb, J., and J. Gyourko (2010), “Can Easy Credit Explain the Housing Boom?,” NBER Working Paper No. 16230.

Head, A., Lloyd-Ellis, H., and H. Sun (2014), "Search, Liquidity, and the Dynamics of House Prices and Construction," American Economic Review, 104, 1172-1210.

Hurst, E., Keys, B., Seru, A., and J.S. Vavra (2016), "Regional Redistribution through the U.S. Mortgage Market," American Economic Review, 106, 2982-3028.

Jorda, O., Schularick, M., and A.M. Taylor (2016), "The Great Mortgaging: Housing Finance, Crises, and Business Cycles,” Economic Policy, 31, 107-152.

Kehrig, M., and N. Ziebarth (2017), "The Effects of the Real Oil Price on Regional Wage Dispersion," American Economic Journal: Macroeconomics, 9, 115-148.

Kilian, L. (2009), "Not All Oil Price Shocks Are Alike: Disentangling Demand and Supply Shocks in the Crude Oil Market," American Economic Review, 99, 1053-1069.

Kilian, L. (2014), “Oil Price Shocks: Causes and Consequences," Annual Review of Resource Economics, 6, 133-154.

Kilian, L. (2016), “The Impact of the Shale Oil Revolution on U.S. Oil and Gas Prices," Review of Environmental Economics and Policy, 10, 185-205.

Kilian, L., Rebucci, A., and N. Spatafora (2009), "Oil Shocks and External Balances," Journal of International Economics, 77, 181-194.

Kilian, L., and C. Vega (2011), “Do Energy Prices Respond to U.S. Macroeconomic News? A 
Test of the Hypothesis of Predetermined Energy Prices," Review of Economics and Statistics, 93, 660-671.

Larson, W.D., and W. Zhao (2017), “Oil Prices and Urban Housing Demand,” forthcoming: Real Estate Economics.

MacDonald, R. (2008), “The Terms of Trade and Domestic Spending,” Analytical Paper No. 018, Statistics Canada.

Mian, A., and A. Sufi (2014), "What Explains the 2007-2009 Drop in Employment?" Econometrica, 82, 2197-2223.

Molloy, R., and H. Shan (2013), "The Effect of Gasoline Prices on Household Location,” Review of Economics and Statistics, 95, 1212-1221.

Muehlenbachs, L., Spiller, E., and C. Timmins (2015), “The Housing Market Impacts of Shale Gas Development," American Economic Review, 105, 3633-3659.

Nocera, A., and M. Roma (2017), "House Prices and Monetary Policy in the Euro Area: Evidence from Structural VARs," ECB Discussion Paper No. 2073.

Saiz, A. (2010), “The Geographic Determinants of Housing Supply,” Quarterly Journal of Economics, 125, 1253-1296.

Sexton, S., Wu, J.J., and D. Zilberman (2012), "How High Gas Prices Triggered the Housing Crisis: Theory and Empirical Evidence," manuscript, University of California at Berkeley.

Yinger, J.M. (2015), Housing and Commuting: The Theory of Urban Residential Structure, World Scientific Publishing, http://faculty.maxwell.syr.edu/jyinger/ebooks/ housing_commuting/table_of_contents.htm. 
Table 1: Sectoral real output responses (province level): Supply-chain linkages

\begin{tabular}{|c|c|c|c|c|}
\hline & \multicolumn{2}{|c|}{ Annual growth } & \multicolumn{2}{|c|}{ Biennial growth } \\
\hline & $\hat{\beta}_{1}^{h}$ & $\hat{\beta}_{2}^{h}$ & $\hat{\beta}_{1}^{h}$ & $\hat{\beta}_{2}^{h}$ \\
\hline Real GDP & $\begin{array}{l}0.0452^{* * *} \\
(0.000)\end{array}$ & $\begin{array}{l}0.0266^{* * *} \\
(0.000)\end{array}$ & $\begin{array}{l}0.0473^{* * *} \\
(0.005)\end{array}$ & $\begin{array}{l}0.0467^{*} \\
(0.057)\end{array}$ \\
\hline $\begin{array}{l}\text { Mining, quarrying \& oil } \\
\text { and gas extraction } \\
\text { - Supporting activities for } \\
\text { mining and oil \& gas } \\
\text { extraction }\end{array}$ & $\begin{array}{l}0.0197^{* * *} \\
(0.002) \\
0.0028^{*} \\
(0.057)\end{array}$ & $\begin{array}{l}0.0166 \\
(0.114) \\
0.0030^{*} \\
(0.062)\end{array}$ & $\begin{array}{l}0.0176^{* *} \\
(0.020) \\
0.0037^{* *} \\
(0.023)\end{array}$ & $\begin{array}{l}0.0251^{*} \\
(0.086) \\
0.0031^{*} \\
(0.090)\end{array}$ \\
\hline Manufacturing & $\begin{array}{l}0.0075^{* * *} \\
(0.000)\end{array}$ & $\begin{array}{l}-0.0011 \\
(0.783)\end{array}$ & $\begin{array}{l}0.0003 \\
(0.490)\end{array}$ & $\begin{array}{l}0.0045^{* *} \\
(0.031)\end{array}$ \\
\hline $\begin{array}{l}\text { - Computer and electronic } \\
\text { products } \\
\text { - Machinery }\end{array}$ & $\begin{array}{l}0.0012^{* * *} \\
(0.003)^{* * *} \\
0.0011^{* * *} \\
(0.000)\end{array}$ & $\begin{array}{l}-0.0006 \\
(0.915) \\
0.0005 \\
(0.260)\end{array}$ & $\begin{array}{l}0.0004^{* *} \\
(0.038) \\
0.0015^{* *} \\
(0.049)\end{array}$ & $\begin{array}{l}-0.0002 \\
(0.743) \\
0.0011 \\
(0.135)\end{array}$ \\
\hline $\begin{array}{l}\text { - Fabricated metal } \\
\text { products } \\
\text { - Transportation } \\
\text { equipment } \\
\text { - Electrical equipment, } \\
\text { appliances, components } \\
\text { - Miscellaneous } \\
\text { manufactures }\end{array}$ & $\begin{array}{l}0.0011^{* * *} \\
(0.003)^{* * *} \\
0.0010^{* * *} \\
(0.057)^{* * *} \\
0.0004^{* * *} \\
(0.000) \\
0.0003^{*} \\
(0.014)\end{array}$ & $\begin{array}{l}-0.0002 \\
(0.699) \\
-0.0006 \\
(0.851) \\
-0.0002 \\
(0.991) \\
-0.0002 \\
(0.950)\end{array}$ & $\begin{array}{l}0.0009^{* *} \\
(0.033) \\
0.0005 \\
(0.321) \\
0.0001 \\
(0.185) \\
0.0000 \\
(0.384)\end{array}$ & $\begin{array}{l}0.0005 \\
(0.223) \\
-0.0001 \\
(0.563) \\
-0.0001 \\
(0.792) \\
0.0000 \\
(0.444)\end{array}$ \\
\hline
\end{tabular}

NOTES: Bootstrap $p$-values in parentheses. ${ }^{*},{ }^{* *}$, and ${ }^{* * *}$ denote statistical significance at the $10 \%, 5 \%$, and $1 \%$ level, respectively. 
Table 2: Sectoral real output responses (province level): Other industries

\begin{tabular}{|c|c|c|c|c|}
\hline & \multicolumn{2}{|c|}{ Annual growth } & \multicolumn{2}{|c|}{ Biennial growth } \\
\hline & $\hat{\beta}_{1}^{h}$ & $\hat{\beta}_{2}^{h}$ & $\hat{\beta}_{1}^{h}$ & $\hat{\beta}_{2}^{h}$ \\
\hline \multirow[t]{2}{*}{ Wholesale trade } & $0.0034^{* * *}$ & 0.0019 & $0.0044^{* * *}$ & 0.0033 \\
\hline & $(0.000)$ & $(0.122)$ & $(0.000)$ & $(0.122)$ \\
\hline \multirow[t]{2}{*}{ Retail trade } & $0.0018^{* * *}$ & 0.0006 & $0.0023^{* * *}$ & 0.0016 \\
\hline & $(0.001)$ & $(0.121)$ & $(0.006)$ & $(0.116)$ \\
\hline \multirow[t]{2}{*}{ Transportation and warehousing } & $0.0005^{*}$ & -0.0002 & -0.0006 & $0.0006^{* *}$ \\
\hline & $(0.057)$ & $(0.361)$ & $(0.878)$ & $(0.035)$ \\
\hline \multirow[t]{2}{*}{ Information and cultural industries } & $0.0012^{* * *}$ & -0.0002 & $0.0011^{* * *}$ & 0.0002 \\
\hline & $(0.000)$ & $(0.178)$ & $(0.000)$ & $(0.257)$ \\
\hline \multirow{4}{*}{$\begin{array}{l}\text { Professional, scientific and } \\
\text { technical services } \\
\text { Business management }\end{array}$} & $0.0019^{* * *}$ & 0.0012 & $0.0024^{* *}$ & $0.0023^{*}$ \\
\hline & $(0.002)$ & $(0.109)$ & $(0.021)$ & $(0.094)$ \\
\hline & $0.0002^{* *}$ & 0.0001 & $0.0005^{* * *}$ & 0.0001 \\
\hline & $(0.017)$ & $(0.291)$ & $(0.000)$ & $(0.234)$ \\
\hline \multirow{4}{*}{$\begin{array}{l}\text { Administrative, support, and other } \\
\text { services } \\
\text { Educational services }\end{array}$} & $0.0009^{* *}$ & -0.0005 & $0.0016^{* * *}$ & 0.0001 \\
\hline & $(0.016)$ & $(0.949)$ & $(0.000)$ & $(0.395)$ \\
\hline & $0.0008^{* * *}$ & 0.0001 & $0.0019^{* * *}$ & -0.0002 \\
\hline & $(0.004)$ & $(0.307)$ & $(0.001)$ & $(0.811)$ \\
\hline \multirow{4}{*}{$\begin{array}{l}\text { Other services (except public } \\
\text { administration) } \\
\text { Public administration }\end{array}$} & $0.0007^{* * *}$ & 0.0002 & $0.0009^{* * *}$ & 0.0004 \\
\hline & $(0.000)$ & $(0.130)$ & $(0.002)$ & $(0.130)$ \\
\hline & $0.0006^{* *}$ & -0.0004 & $0.0027^{* * *}$ & -0.0007 \\
\hline & $(0.025)$ & $(0.928)$ & $(0.000)$ & $(0.982)$ \\
\hline \multirow[t]{2}{*}{ Utilities } & $0.0018^{* * *}$ & -0.0002 & $0.0019^{* * *}$ & -0.0006 \\
\hline & $(0.000)$ & $(0.713)$ & $(0.000)$ & $(0.961)$ \\
\hline \multirow[t]{2}{*}{ Construction } & $0.0053^{*}$ & $0.0075^{*}$ & $0.0095^{* *}$ & 0.0071 \\
\hline & $(0.091)$ & $(0.051)$ & $(0.021)$ & $(0.109)$ \\
\hline \multirow{2}{*}{$\begin{array}{l}\text { Agriculture, forestry, fishing and } \\
\text { hunting }\end{array}$} & $0.0023^{*}$ & 0.0011 & 0.0023 & $0.0025^{* *}$ \\
\hline & $(0.081)$ & $(0.148)$ & $(0.222)$ & $(0.037)$ \\
\hline
\end{tabular}

NOTES: Bootstrap $p$-values in parentheses. ${ }^{*},{ }^{* *}$, and ${ }^{* * *}$ denote statistical significance at the $10 \%, 5 \%$, and $1 \%$ level, respectively.

Table 3: Average magnitude of equalization transfers received and average motor fuel expenditures in 2016 dollars (by province), 2009-2016

\begin{tabular}{lccc}
\hline \hline Province & $\begin{array}{c}\text { Equalization transfer } \\
\text { \$ per capita }\end{array}$ & $\begin{array}{c}\text { Motor fuel spending } \\
\text { \$ per capita }\end{array}$ & $\begin{array}{c}\text { Excess transfer } \\
\text { \$ per capita }\end{array}$ \\
\hline Manitoba & 1,507 & 656 & 851 \\
Ontario & 161 & 708 & -547 \\
Quebec & 1,108 & 609 & 499 \\
New Brunswick & 2,243 & 830 & 1,413 \\
Nova Scotia & 1,585 & 718 & 867 \\
\hline Average & 1,321 & 708 & 613 \\
\hline
\end{tabular}

NOTES: The data on the equalization transfers are from the Canadian Department of Finance. Motor fuel spending is from household surveys, as reported by Statistics Canada. The motor fuel spending per household has been divided by the average number of household members. 
Table 4: Government revenue and government spending responses to real oil price shocks (province level)

\begin{tabular}{lcc}
\hline & \multicolumn{2}{c}{ Annual growth } \\
\cline { 2 - 3 } & $\hat{\beta}_{1}^{h}$ & $\hat{\beta}_{2}^{h}$ \\
\hline Revenue & $0.038(0.199)$ & $0.123(0.007)^{* * *}$ \\
Expenditure & $0.026(0.091)^{*}$ & $0.028(0.068)^{*}$ \\
\cline { 2 - 3 } & \multicolumn{2}{c}{ Biennial growth } \\
\hline Revenue & $\hat{\beta}_{1}^{h}$ & $\hat{\beta}_{2}^{h}$ \\
Expenditure & $0.075(0.067)^{*}$ & $0.100(0.032)^{* *}$ \\
\hline
\end{tabular}

NOTES: Bootstrap $p$-values shown in parentheses. ${ }^{*},{ }^{* *}$, and ${ }^{* * *}$ denote statistical significance at the $10 \%, 5 \%$, and $1 \%$ level, respectively.

Figure 1: Real house prices and the real price of oil in Canada, 1999.3- 2017.8
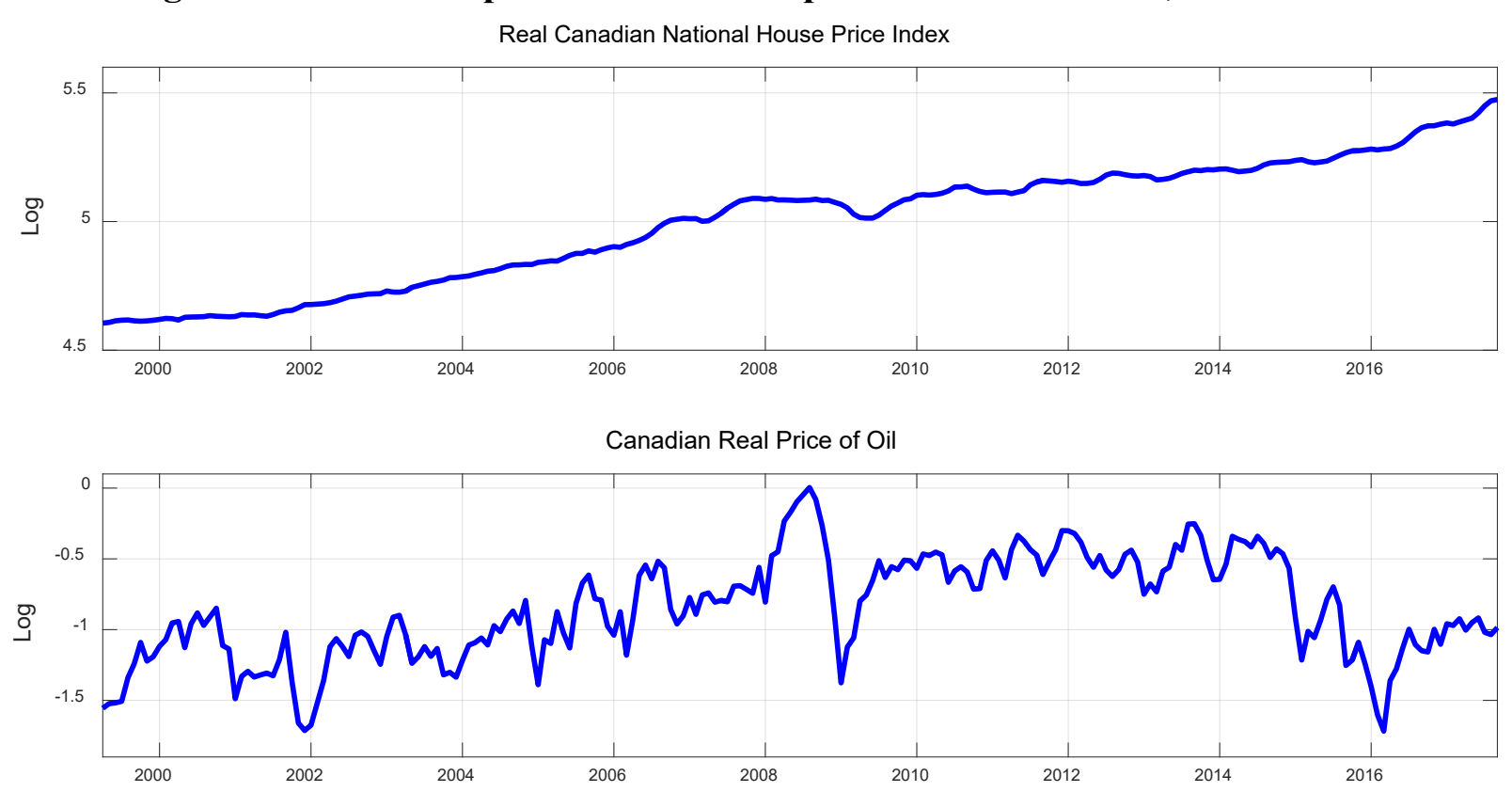

NOTES: The monthly Canadian national house price index is from Teranet-National Bank and is based on the change in home prices in 11 metropolitan areas. The nominal price of oil is the price of Western Canada Select (WCS) crude oil. Both time series have been deflated by the CPI. 
Figure 2: The effect of selected shocks on real national house prices, 1999.3-2017.8
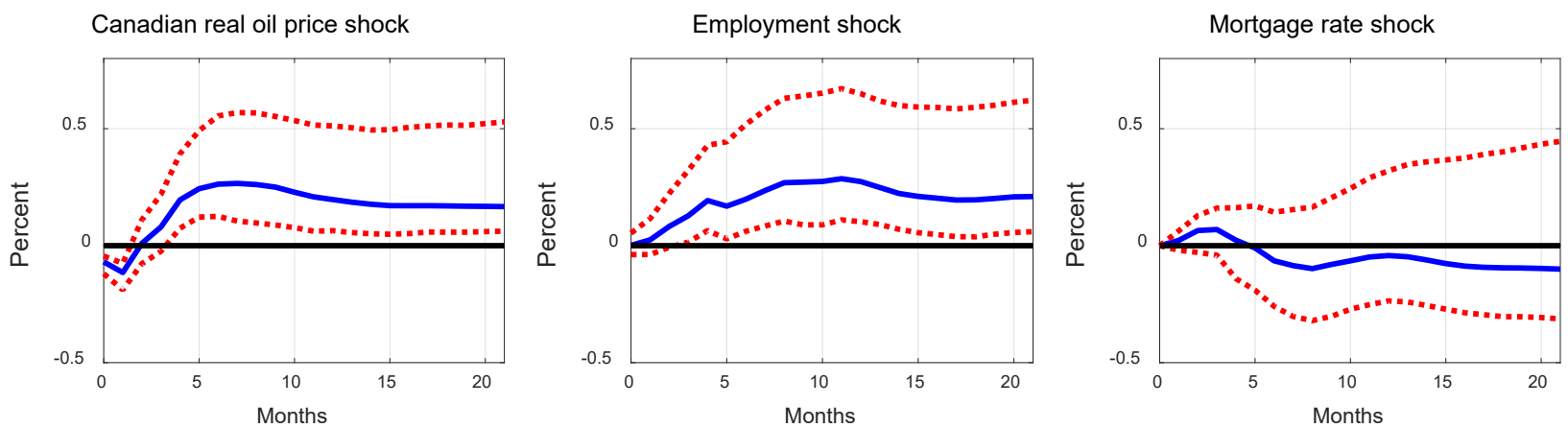

NOTES: Responses to one-standard-deviation shocks based on the VAR model in section 2.1. The 90\% confidence intervals were constructed based on the conditional heteroskedasticity-robust residual block bootstrap of Brüggemann, Jentsch and Trenkler (2016) with block size 24.

Figure 3: The effect of an unexpected increase in the Canadian real price of oil on selected Canadian macroeconomic aggregates, 1999.3-2017.8
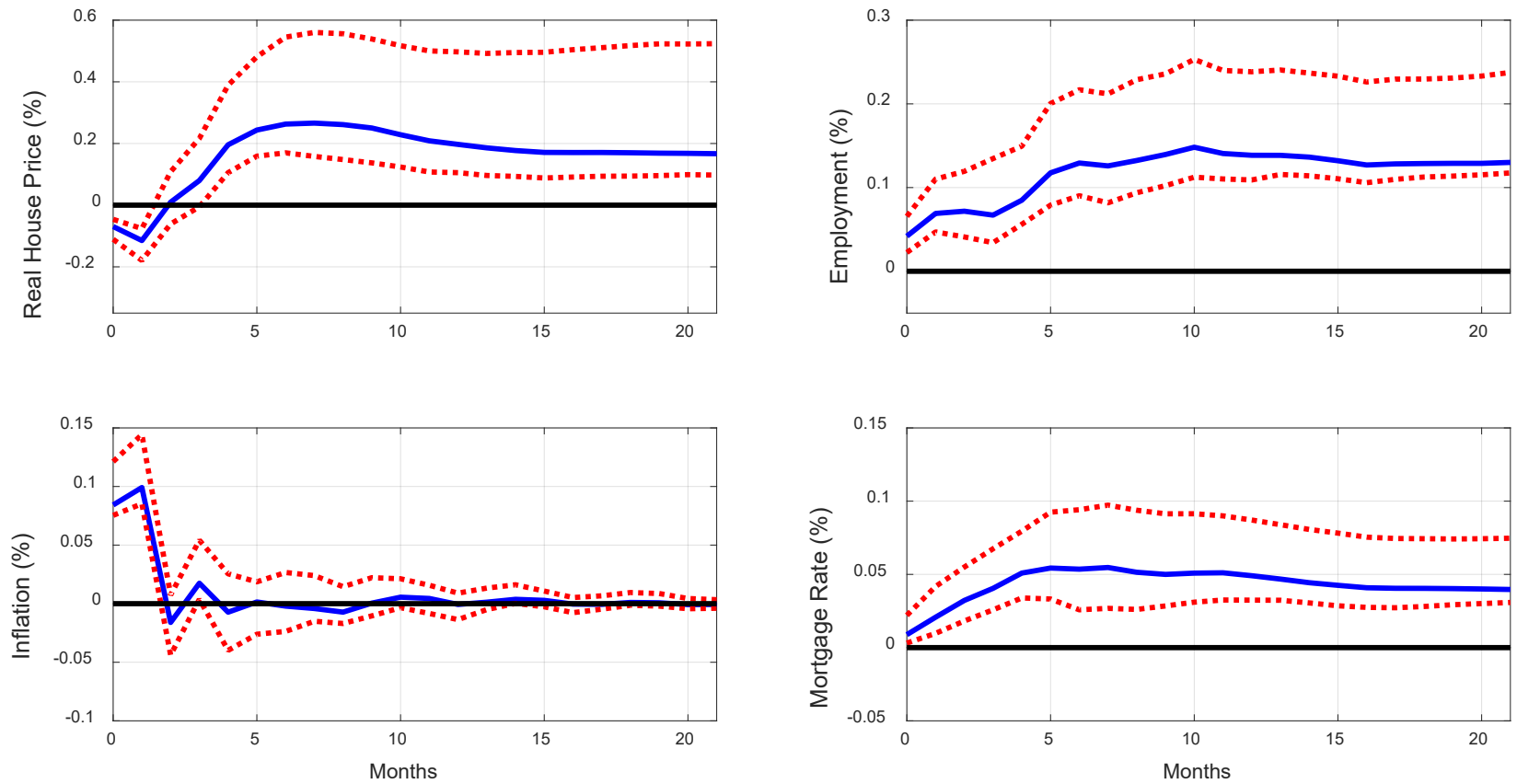

NOTES: Responses to one-standard-deviation shock based on the VAR model in section 2.1. The 90\% confidence intervals were constructed based on the conditional heteroskedasticity-robust residual block bootstrap of Brüggemann, Jentsch and Trenkler (2016) with block size 24. 
Figure 4: The effect of an unexpected increase in the U.S. real price of oil on selected Canadian macroeconomic aggregates, 1999.3-2017.8
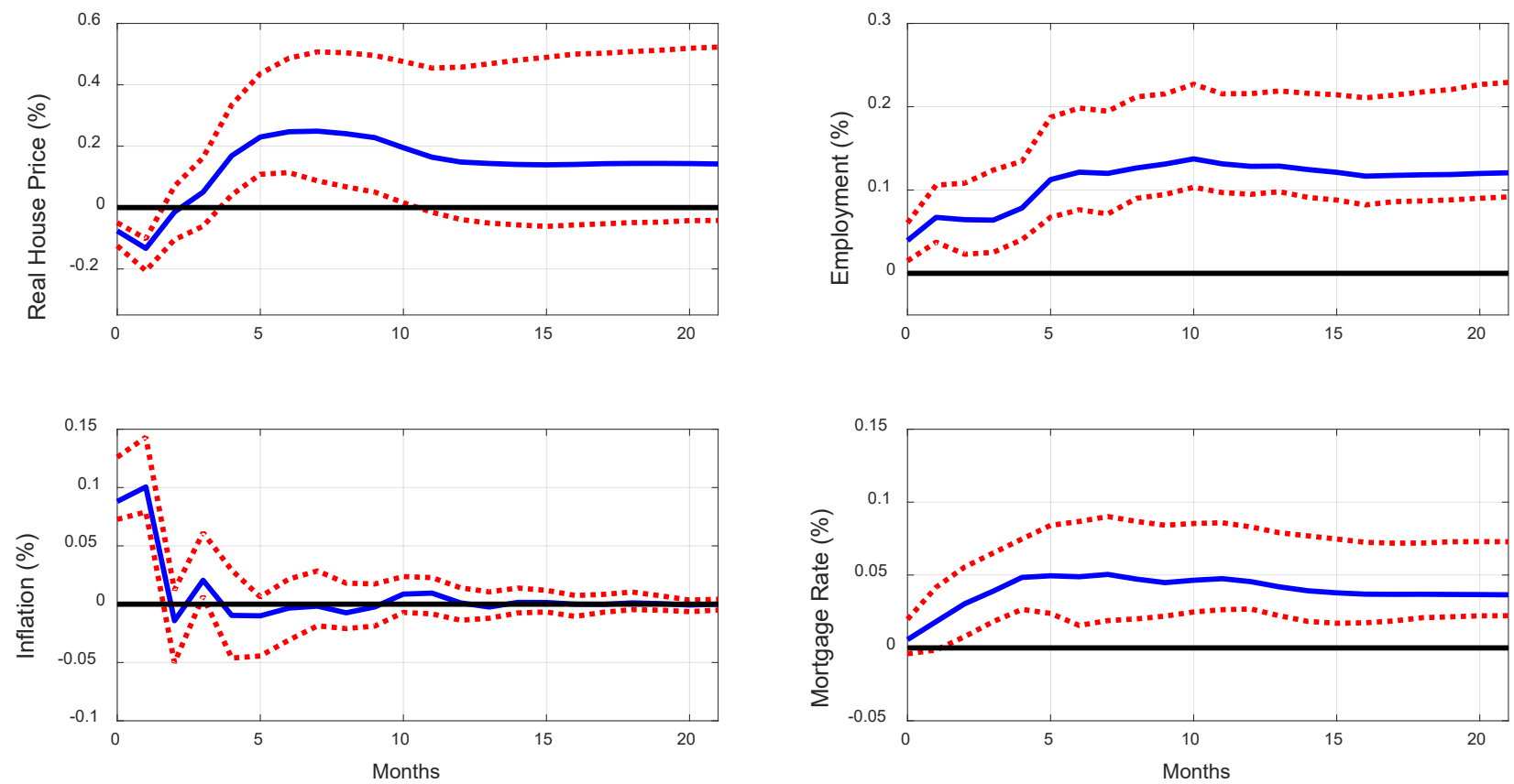

NOTES: Responses to one-standard-deviation shock based on the VAR model in section 2.2. The 90\% confidence intervals were constructed based on the conditional heteroskedasticity-robust residual block bootstrap of Brüggemann, Jentsch and Trenkler (2016) with block size 24.

Figure 5: Standardized employment shares for selected Canadian cities

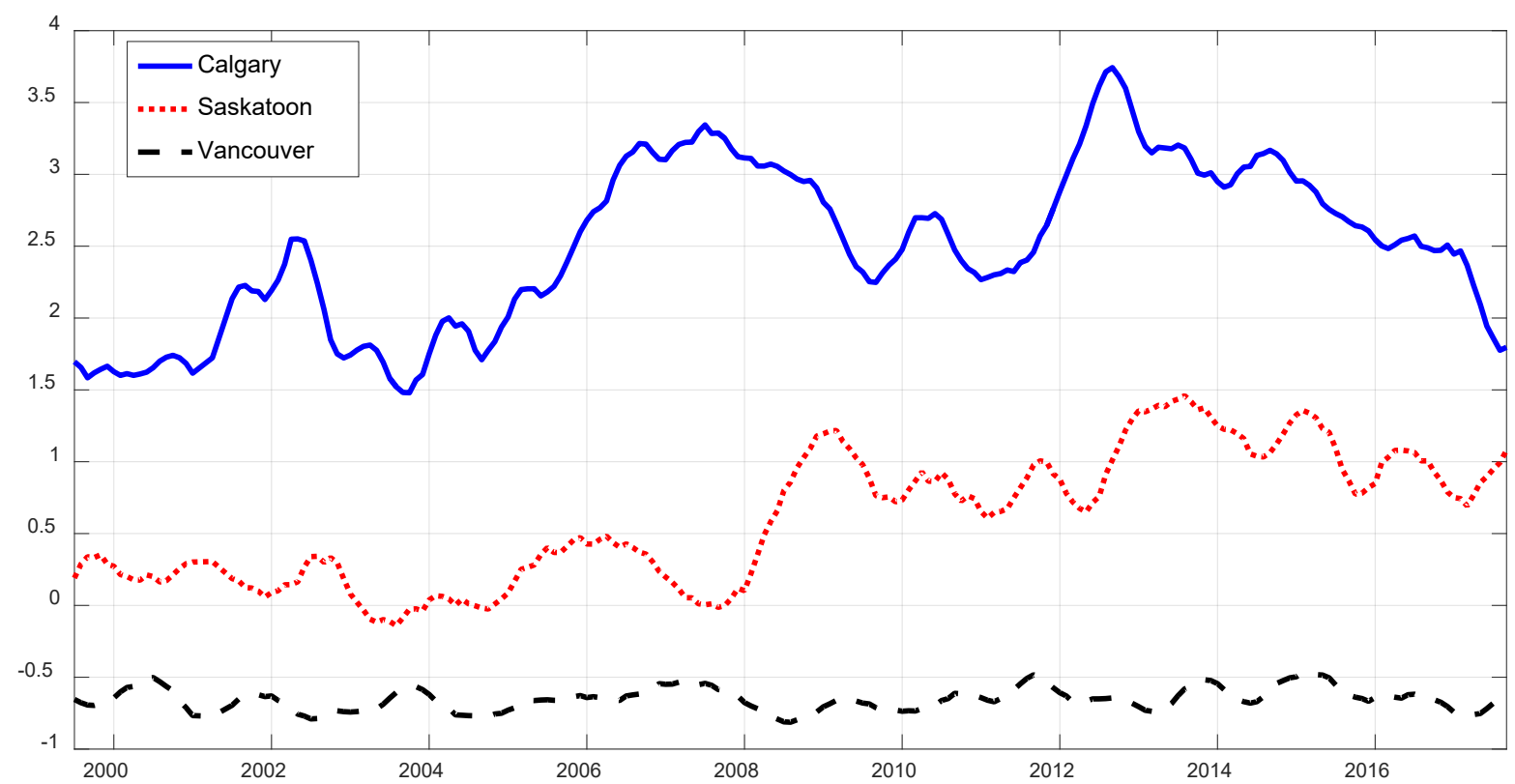


Figure 6: Housing market responses to a positive 1\% real oil price shock (city level)
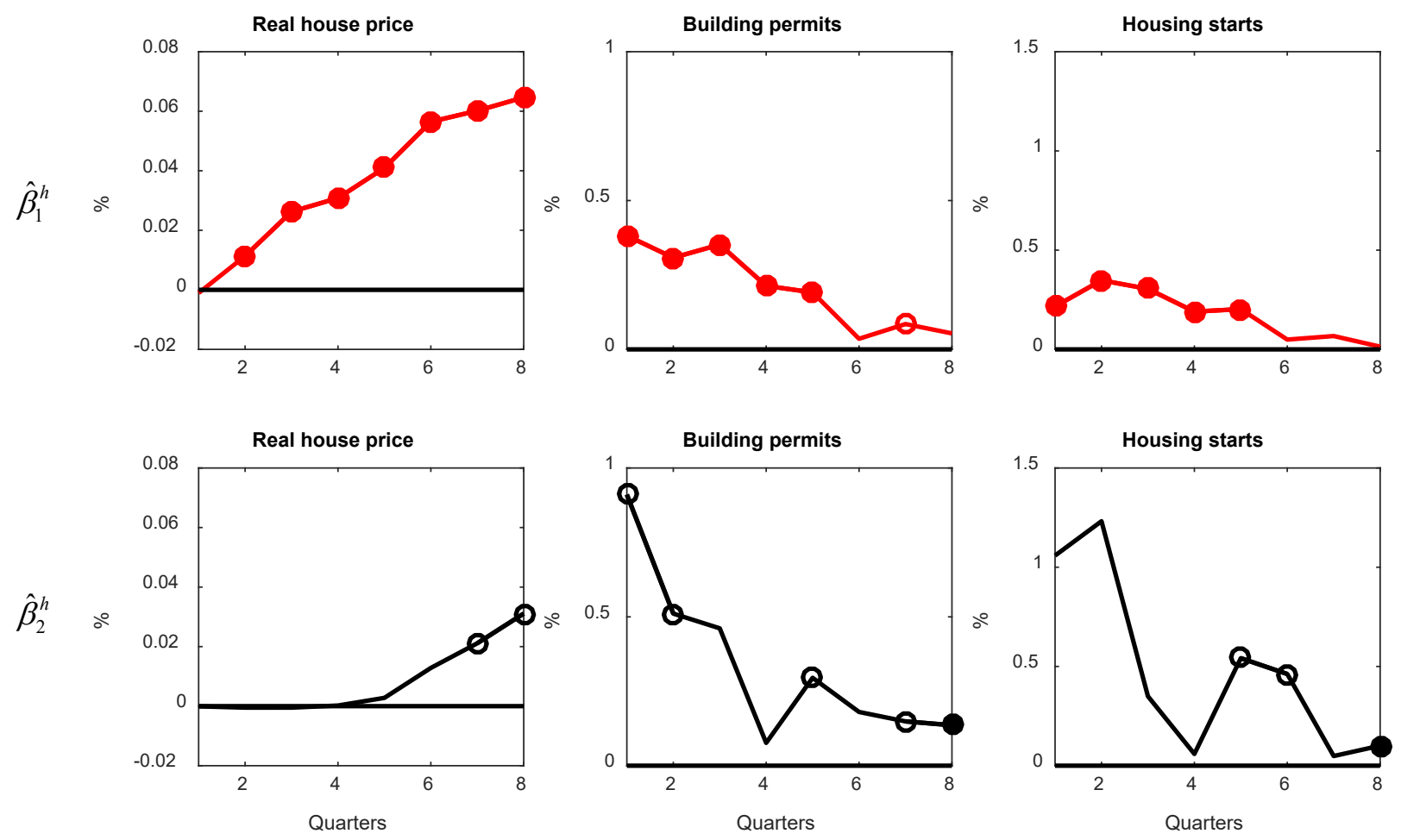

Figure 7: Responses of mortgage markets to a positive $1 \%$ real oil price shock (province level)
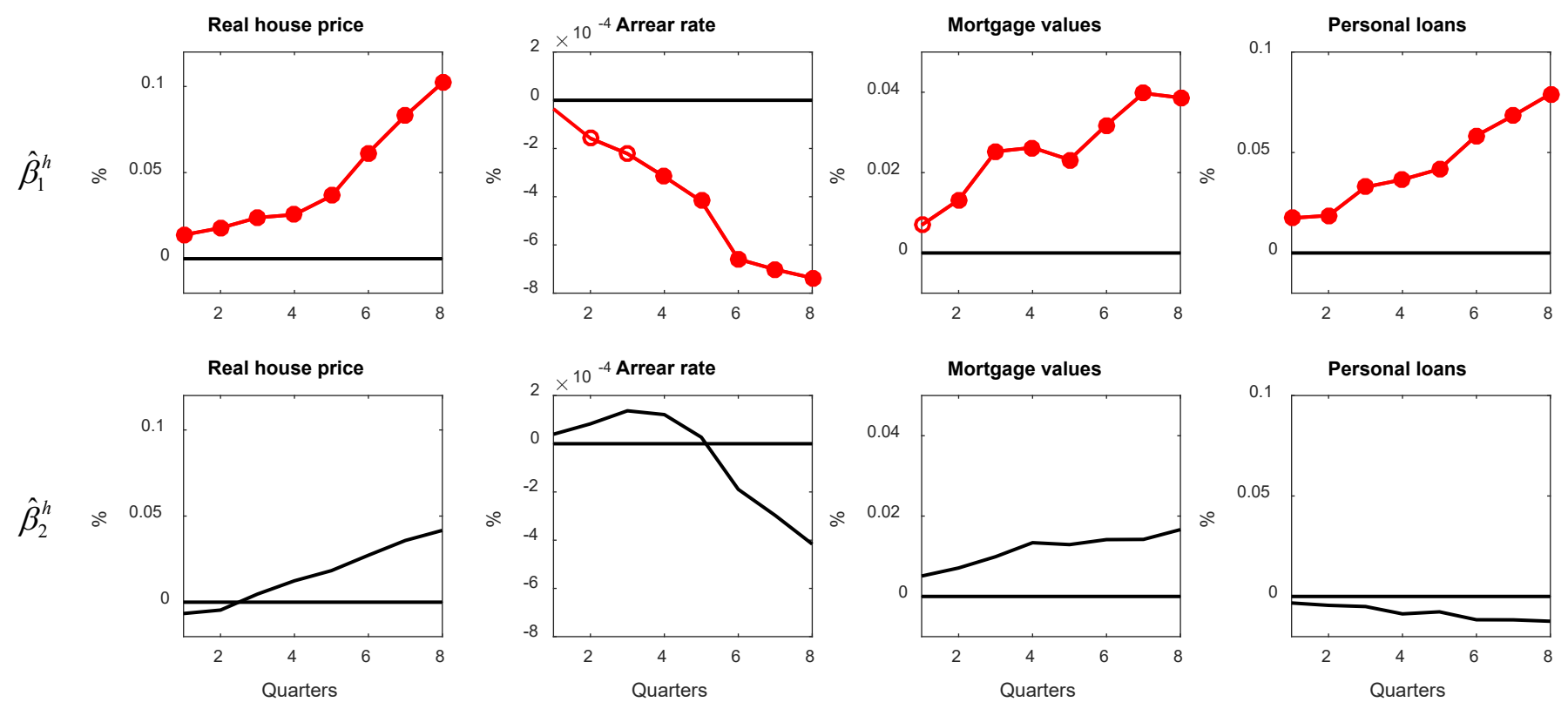
Figure 8: Labor market responses to a positive $1 \%$ real oil price shock (city level)
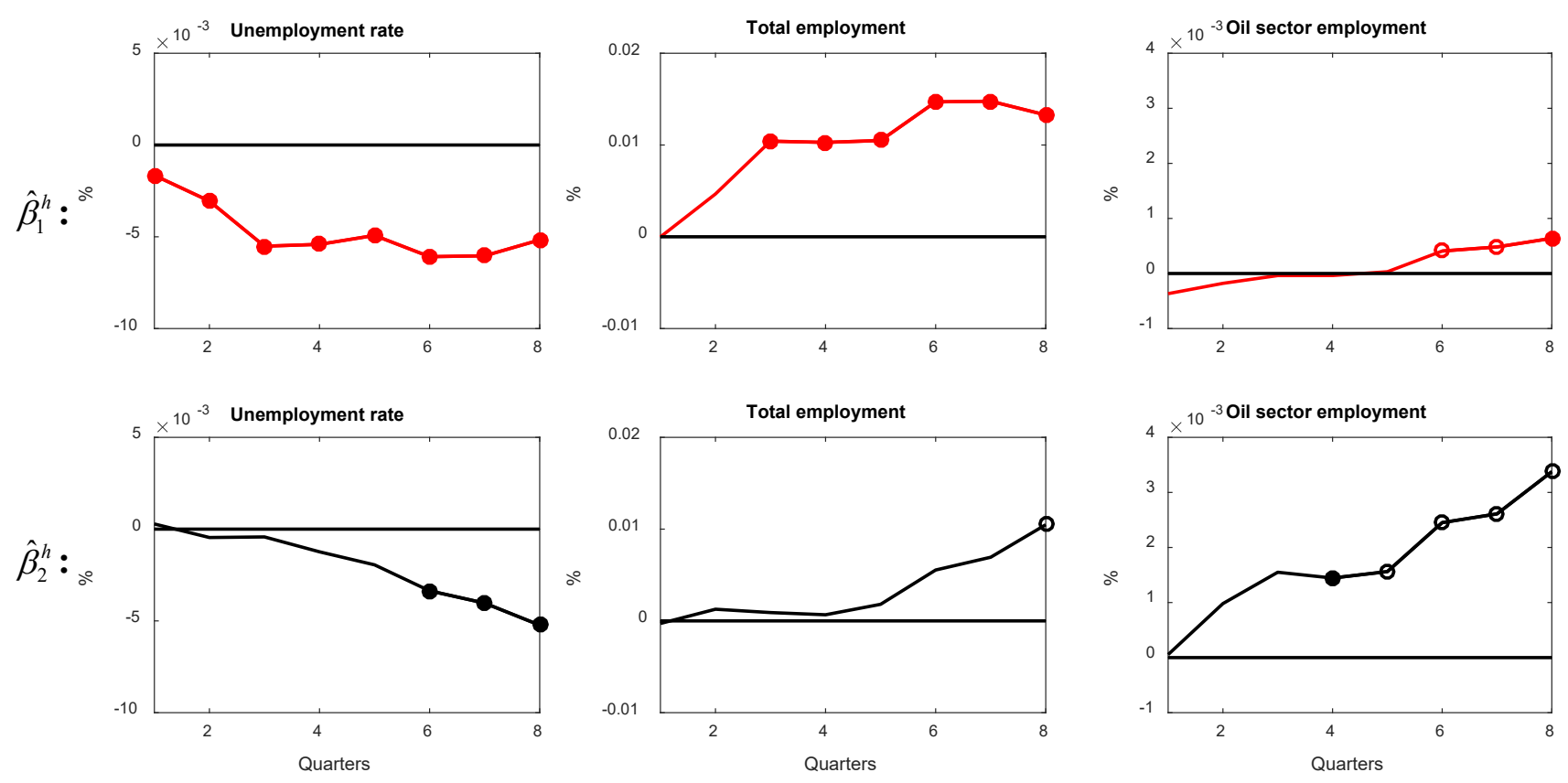


\section{Not-for-Publication Appendix:}

Figure A1: Net migration responses to a positive $1 \%$ real oil price shock (province level)
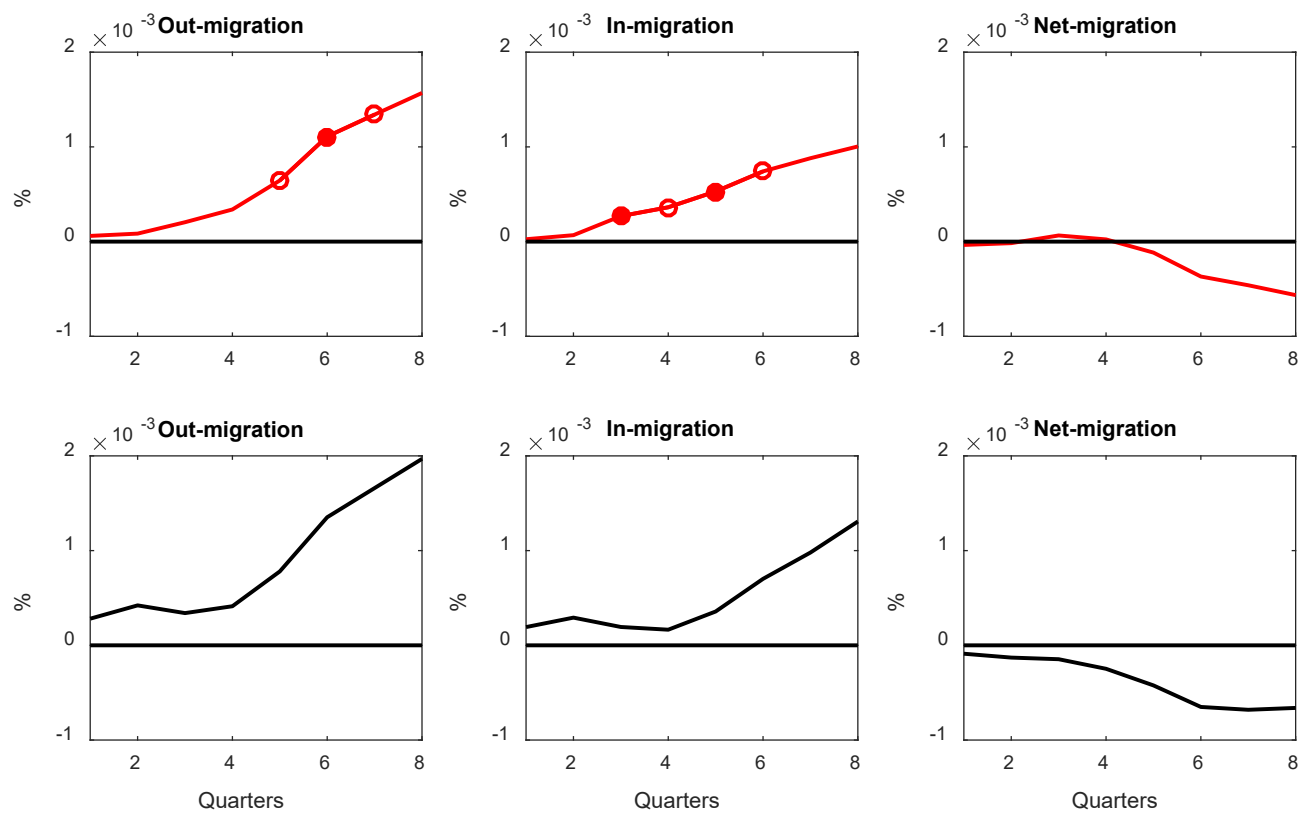

NOTES: Based on quarterly estimates of interprovincial in- and out-migration from Canada Revenue Agency (CRA) tax data showing changes in permanent residence.

Figure A2: Interprovincial net migration and the real oil price of oil
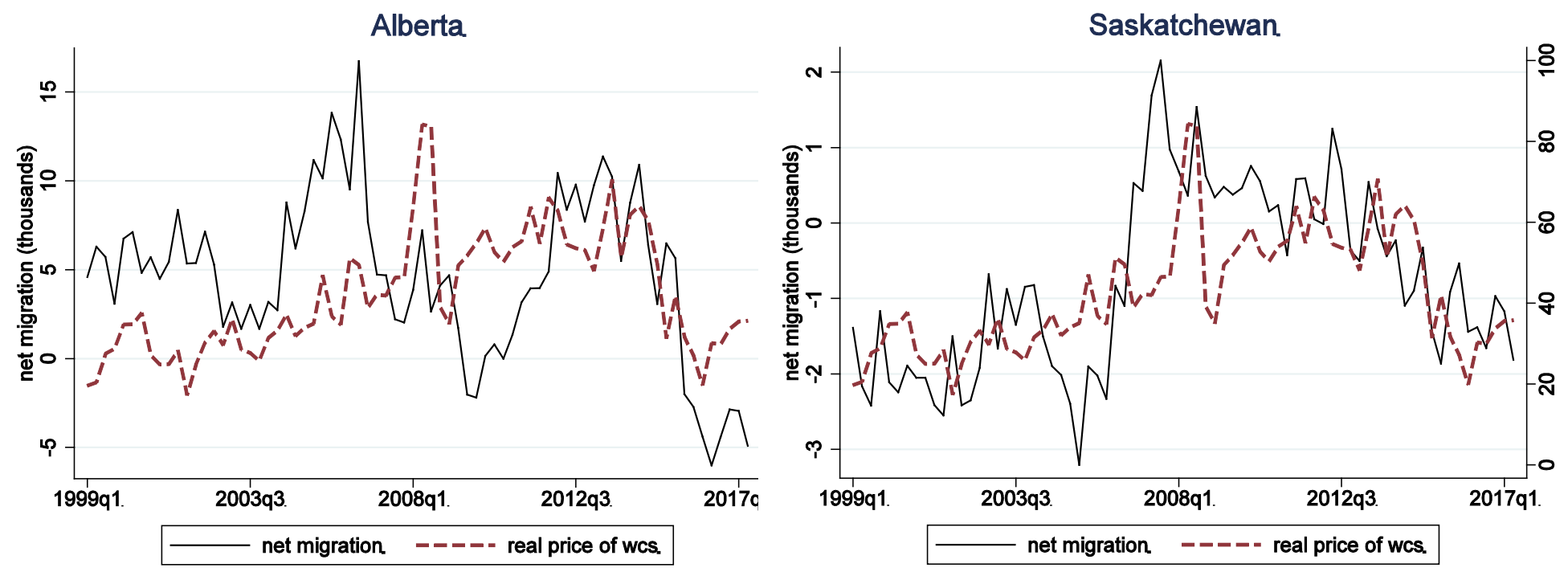

Notes: See Figure A1. 
Figure A3: Response of aircraft movements to a positive 1\% real oil price shock
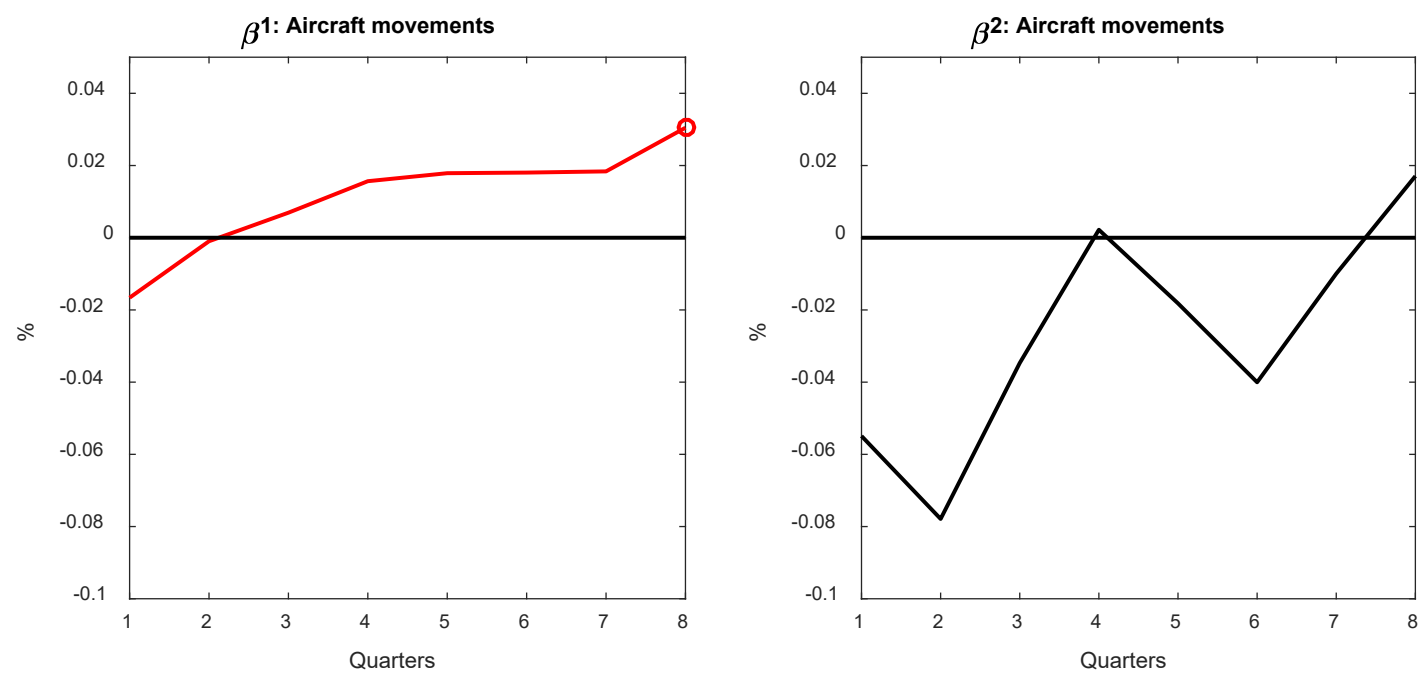

NOTES: Total number of aircraft movements in city airports with Nav Canada towers. 